\title{
Cancer effects of formaldehyde: a proposal for an indoor air guideline value
}

\author{
Gunnar Damgård Nielsen · Peder Wolkoff
}

Received: 18 January 2010/Accepted: 19 April 2010/Published online: 14 May 2010

(c) The Author(s) 2010. This article is published with open access at Springerlink.com

\begin{abstract}
Formaldehyde is a ubiquitous indoor air pollutant that is classified as "Carcinogenic to humans (Group 1)" (IARC, Formaldehyde, 2-butoxyethanol and 1-tert-butoxypropanol-2-ol. IARC monographs on the evaluation of carcinogenic risks to humans, vol 88. World Health Organization, Lyon, pp 39-325, 2006). For nasal cancer in rats, the exposure-response relationship is highly non-linear, supporting a no-observed-adverse-effect level (NOAEL) that allows setting a guideline value. Epidemiological studies reported no increased incidence of nasopharyngeal cancer in humans below a mean level of $1 \mathrm{ppm}$ and peak levels below $4 \mathrm{ppm}$, consistent with results from rat studies. Rat studies indicate that cytotoxicity-induced cell proliferation (NOAEL at $1 \mathrm{ppm}$ ) is a key mechanism in development of nasal cancer. However, the linear unit risk approach that is based on conservative ("worst-case") considerations is also used for risk characterization of formaldehyde exposures. Lymphohematopoietic malignancies are not observed consistently in animal studies and if caused by formaldehyde in humans, they are high-dose phenomenons with non-linear exposure-response relationships. Apparently, these diseases are not reported in epidemiological studies at peak exposures below $2 \mathrm{ppm}$ and average exposures below $0.5 \mathrm{ppm}$. At the similar airborne exposure levels in rodents, the nasal cancer effect is much more prominent than lymphohematopoietic malignancies. Thus, prevention of nasal cancer is considered to prevent lymphohematopoietic malignancies. Departing from the rat studies, the guideline value of the WHO (Air quality guidelines for Europe, 2nd edn. World Health Organization,
\end{abstract}

G. D. Nielsen $(\bowtie) \cdot$ P. Wolkoff

National Research Centre for the Working Environment, Lers $\varnothing$ Parkallé 105, 2100 Copenhagen $\varnothing$, Denmark

e-mail: gdn@nrcwe.dk
Regional Office for Europe, Copenhagen, pp 87-91, 2000), $0.08 \mathrm{ppm}\left(0.1 \mathrm{mg} \mathrm{m}^{-3}\right)$ formaldehyde, is considered preventive of carcinogenic effects in compliance with epidemiological findings.

Keywords Formaldehyde - Cancer - Risk assessment . Indoor air guideline

$\begin{array}{ll}\text { Abbreviations } \\ \text { CI } & \text { Confidence interval } \\ \text { DPX } & \text { DNA-protein crosslink(s) } \\ \text { FA } & \text { Formaldehyde } \\ \text { GSH } & \text { Glutathione } \\ \text { GLP } & \text { Good laboratory practice } \\ \text { MN } & \text { Micronucleus/micronuclei } \\ \text { ICD } & \text { International classification of diseases } \\ \text { NALT } & \text { Nasopharyngeal-associated lymphoid tissue } \\ \text { NOAEL } & \text { No-observed-adverse-effect level } \\ \text { RR } & \text { Relative risk } \\ \text { PMR } & \text { Proportional mortality ratio } \\ \text { SCC } & \text { Squamous cell carcinoma } \\ \text { SCE } & \text { Sister-chromatid exchange } \\ \text { SMR } & \text { Standardized mortality ratio } \\ \text { TWA } & \text { Time-weighted average } \\ \text { UR } & \text { Unit risk }\end{array}$

\section{Introduction}

As a natural compound, formaldehyde (FA) occurs in unpolluted ambient air at concentrations usually below $1 \mu \mathrm{g} \mathrm{m}^{-3} ; 1 \mathrm{ppb}$ is equal to $1.23 \mu \mathrm{g} \mathrm{m}^{-3}$ at 1 atmosphere and $25^{\circ} \mathrm{C}$. In urban environments, concentrations are 
usually in the range of $1-20 \mu \mathrm{g} \mathrm{m}^{-3}$, but may be in areas with heavy traffic up to $100 \mu \mathrm{g} \mathrm{m}^{-3}$ (IARC 2006).

Formaldehyde is a ubiquitous pollutant in indoor air with a mean global concentration range of 4 to $>600 \mu \mathrm{g} \mathrm{m}^{-3}$ where reported concentrations varied greatly across countries (IARC 2006). In Canada, the median indoor air level was about $30 \mu \mathrm{g} \mathrm{m}^{-3}$ with the upper 90th percentile about 60-70 $\mu \mathrm{g} \mathrm{m}^{-3}$ (Liteplo and Meek 2003). The indoor air exposures in non-manufacturing offices or schools in the US varied from 5 to $80 \mu \mathrm{g} \mathrm{m}^{-3}$, estimated from Dodson et al. (2007). The indoor air concentrations of FA were investigated in eight cities in different European countries; the mean concentrations varied from 14 to $31 \mu \mathrm{g} \mathrm{m}^{-3}$ (de Bruin et al. 2008). In a comparative study of Uppsala/ Sweden and Nagoya/Japan, the mean indoor air FA level was $8.3 \mu \mathrm{g} \mathrm{m}^{-3}$ (maximum: $19 \mu \mathrm{g} \mathrm{m}^{-3}$ ) and $17.6 \mu \mathrm{g} \mathrm{m}^{-3}$ (maximum: $73 \mu \mathrm{g} \mathrm{m}^{-3}$ ), respectively (Sakai et al. 2004). In German residences, a survey from 2003 to 2006 showed that the median FA concentration was $24 \mu \mathrm{g} \mathrm{m}^{-3}$ and the 95th percentile $48 \mu \mathrm{g} \mathrm{m}^{-3}$ (Salthammer et al. 2010).

Formaldehyde is a known nasal carcinogen in rats and considered a human carcinogen (IARC 2006). The evaluation of carcinogenic risks due to FA in indoor air is based on two mutually incompatible approaches. The unit risk (UR) approach assumes a non-threshold approach with low-dose linear extrapolation and the threshold approach which assumes an exposure below where no cancer risk exists. In the allocation of resources to prevent low dose FA levels, the two approaches predict tremendous differences in pay back. This study evaluates the recent literature relevant for risk assessment of low-dose exposure effects with the purpose to propose a health-based indoor air guideline for prevention of cancer due to indoor air FA exposures.

Recently, FA was re-evaluated for carcinogenic effects and reclassified as "Carcinogenic to humans (Group 1)" (IARC 2006). In addition to sufficient evidence in animal studies for nasal carcinogenicity of FA, the IARC concluded that there is sufficient epidemiological evidence that FA causes nasopharyngeal cancer in humans. This was based on results from the US National Cancer Institute (NCI) cohort and supported by the primarily positive findings in other studies. Recently, the IARC accepted that there is sufficient evidence for FA inducing leukemia, particularly myeloid leukemia (Baan et al. 2009), which was further supported by a recent study of embalmers (Hauptmann et al. 2009) and by chromosomal aberrations in myeloid progenitor cells (Baan et al. 2009) in a small group of FA-exposed Chinese workers (Zhang et al. 2010). The IARC (2006) found only limited epidemiological evidence that FA causes sinonasal cancer in humans and the overall balance of epidemiological evidence did not support a causal role for FA-induced cancer at other sites, including the oral cavity, oro- and hypopharynx, pancreas, larynx, lung and brain.

Formaldehyde is genotoxic in multiple in vitro models and in exposed humans and laboratory animals (IARC 2006; SCOEL 2008). Genotoxicity and cytotoxicity are considered to play important roles in the carcinogenesis of FA in nasal tissues (IARC 2006) in which cell proliferation due to cytotoxicity is considered to be a key element in the development of upper airway cancer (McGregor et al. 2006; SCOEL 2008). For this type of carcinogenic effects, the no-observed-adverse-effect level (NOAEL) and the use of assessment factors are considered appropriate for setting standards or guidelines for airborne exposures (Nielsen and $\emptyset v r e b \varnothing 2008)$. The NOAEL approach has been used for setting health-based occupational exposure limits for FA, for example, in Europe (SCOEL 2008), Germany (DFG 2009), USA. (ACGIH 2007) and Japan (Omae 2007). Furthermore, the approach has been used for setting an outdoor air standard as well as an indoor air guideline in Germany (Appel et al. 2006; Empfehlung des Umweltbundesamtes 2006; Salthammer et al. 2010), and proposed for setting an outdoor standard by Japanese scientists (Naya and Nakanishi 2005). The World Health Organization has proposed an air quality guideline of $0.08 \mathrm{ppm}$ $\left(0.1 \mathrm{mg} \mathrm{m}^{-3}\right.$ ) (WHO 2000) for prevention of eye and airway irritation, and nasal cancer.

The UR, which is based on a non-threshold concept, has also been applied for risk characterization of FA exposures (e.g. Wu et al. 2003; Sax et al. 2006; Azuma et al. 2007; Dodson et al. 2007; Loh et al. 2007). In this case, it is assumed that the cancer risk of a compound is linearly related to the exposure in the low-dose range. The UR is the estimated lifetime risk at lifelong exposure to $1 \mu \mathrm{g} \mathrm{m} \mathrm{m}^{-3}$ of the compound. The UR is calculated from non-threshold mathematical functions assuming that these apply outside the range of experimental observations to yield estimates of risks at the lower doses (e.g. Cal EPA 2005). For example, the UR has been estimated to $1.3 \times 10^{-5}$ (IRIS 1991) and $6 \times 10^{-6}(\mathrm{Cal}$ EPA 2005).

\section{Methods}

Studies published in English in peer-reviewed journals are considered; the literature search strategies are indicated in the "Appendix".

We have attempted to avoid interpretation of non-significant statistical trends as they may be due either to lack of statistical power or due to spurious associations, which cannot be distinguished scientifically. However, this is not always possible in the epidemiological studies. Epidemiological studies with multiple exposure relationships and thus many statistical tests are especially prone to spurious 
associations. Additionally, false-positive results due to unadjusted confounder effects may occur. Therefore, hazard identification from epidemiological studies has been performed from meta-analyses to maximize consistency across studies. The exposure-dependent effects in epidemiological studies are based on the three largest cohort studies as their exposure assessments were based on measured FA concentrations.

\section{Biological mechanisms}

Chronic exposure to $\geq 6$ ppm FA caused exposure-dependent neoplasia of the nasal epithelium, mainly squamous cell carcinomas (SCC) in rats with a non-linear concentration-response relationship (Table 1). The NOAEL for development of SCC was 2 ppm (Monticello et al. 1996) as also suggested from Table 1, showing the frequency of detected SCC. Overall, animal data also suggest that organs which are not in direct contact with FA do not develop neoplasms, presumably due to the fact that FA is highly reactive and rapidly metabolized locally (Bosetti et al. 2008; Heck and Casanova 2004; McGregor et al. 2006).

In the nasal tissue, FA reacts with glutathione (GSH) and forms $S$-hydroxymethyl-GSH, which is oxidized by the FA-dependent alcohol dehydrogenase. This results in the production of formate (IARC 2006; McGregor et al. 2006). In rats, half saturation of the enzyme is estimated to occur at $2.6 \mathrm{ppm}$ FA (Casanova et al. 1989) and, thus, higher exposure levels cause a disproportionate increase in cellular levels of FA (Casanova et al. 1989). As FA is highly reactive, it can cross-link DNA and proteins in cells, which is considered the primary genotoxic effect of FA (Liu et al. 2006; Schmid and Speit 2007). The formation of DNAprotein cross-links (DPX) in nasal tissue shows a biphasic concentration-response relationship (Casanova et al. 1989, 1994). A conspicuous increase in DPX formation occurs above 2-3 ppm (Casanova et al. 1989, 1994), where carcinogenic effect has been observed in rats (Table 1). The formation of DPX may be linearly related to the FA concentration at or below 0.7 ppm (Casanova et al. 1989, 1994). In vivo studies showed that DPX was not accumulated over repeated exposures in rat nasal tissue (Casanova et al. 1994). At a similar exposure level, the DPX level was an order of magnitude higher in rats than in the nasal mucosa in monkeys, and monkeys are considered to have a higher DPX level than humans (Casanova et al. 1991; Heck and Casanova 2004). In consequence, no assessment factor is needed for extrapolation from rats to humans, which has been used in the risk characterization.

The development of SCC is considered to be related to a genotoxic effect caused by DPX (Merk and Speit 1998; Appel et al. 2006; McGregor et al. 2006) in addition to cytolethality-regenerative cellular proliferation (Conolly et al. 2003; McGregor et al. 2006). Increase in the cell proliferation in the rat nose is considered to occur at about

Table 1 Nasal epithelial squamous cell carcinomas (SCCs) in male (M) and female (F) rats at long-term inhalation exposures to formaldehyde

\begin{tabular}{|c|c|c|c|c|c|c|}
\hline \multirow[t]{2}{*}{ Concentration range $^{\mathrm{a}}(\mathrm{ppm})$} & \multicolumn{2}{|l|}{$1^{\mathrm{b}}$} & \multirow{2}{*}{$\begin{array}{l}2^{\mathrm{c}} \\
\mathrm{M}(\%)\end{array}$} & \multirow{2}{*}{$\begin{array}{l}3^{\mathrm{d}} \\
\mathrm{M}(\%)\end{array}$} & \multirow{2}{*}{$\begin{array}{l}4^{\mathrm{e}} \\
\mathrm{M}(\%)\end{array}$} & \multirow{2}{*}{$\begin{array}{l}5^{\mathrm{f}} \\
\mathrm{M}(\%)\end{array}$} \\
\hline & $\mathrm{M}(\%)$ & $\mathrm{F}(\%)$ & & & & \\
\hline 0 & $0 / 118(0)$ & $0 / 114(0)$ & 0/99 (0) & 0/90 (0) & $0 / 26(0)$ & $0 / 32(0)$ \\
\hline 0.1 & - & - & - & - & $1 / 26(3.8)$ & - \\
\hline 0.3 & - & - & - & - & - & $0 / 32(0)$ \\
\hline 0.7 & - & - & - & 0/90 (0) & - & - \\
\hline 1 & - & - & - & - & $1 / 28(3.6)$ & - \\
\hline 2 & $0 / 118(0)$ & $0 / 118(0)$ & - & 0/96 (0) & - & $0 / 32(0)$ \\
\hline 6 & $1 / 119(0.8)$ & $1 / 116(0.9)$ & - & $1 / 90(1.1)$ & - & - \\
\hline 10 & - & - & - & $20 / 90(22)$ & $1 / 26(3.8)$ & - \\
\hline 14 & $51 / 117(44)$ & $52 / 115(45)$ & - & - & - & - \\
\hline 15 & - & - & 38/99 (38) & 69/147 (47) & - & $13 / 32(41)$ \\
\hline
\end{tabular}

${ }^{a}$ For exact concentrations, see the other footnotes

${ }^{\mathrm{b}}$ Exposures were to 0, 2.0, 5.6 or $14.3 \mathrm{ppm}, 6 \mathrm{~h}_{\text {day }}^{-1}, 5$ days week $^{-1}$ for 24 months in Fischer 344 rats which was followed by 6 months of non-exposure (Kerns et al. 1983). The numerator is the number of animals with SCC and the denominator is the number of nasal cavities evaluated. The percentage is given in parenthesis

${ }^{\mathrm{c}}$ Exposures were to 0 or $14.8 \mathrm{ppm}$ lifetime, $6 \mathrm{~h} \mathrm{day}^{-1}, 5$ days week ${ }^{-1}$ in Sprague-Dawley rats (Sellakumar et al. 1985)

${ }^{\mathrm{d}}$ Exposures were to 0, 0.69, 2.05, 6.01, 9.93 or $14.96 \mathrm{ppm}, 6 \mathrm{~h} \mathrm{day}^{-1}, 5$ days week $^{-1}$ for 24 months in Fischer 344 rats (Monticello et al. 1996)

e Exposures were to 0, 0.1, 1 or $9.8 \mathrm{ppm}, 6 \mathrm{~h} \mathrm{day}^{-1}, 5$ days week $^{-1}$ for 28 months in Wistar rats (Woutersen et al. 1989). This study did not show an exposure-dependent development of SCC, for further discussion, see the text

${ }^{\mathrm{f}}$ Fisher 344 rats were exposed $6 \mathrm{~h} \mathrm{day}^{-1}, 5$ days week $^{-1}$ for 28 months to 0, 0.30, 2.17 or 14.85 ppm (Kamata et al. 1997) 
2 ppm FA and above (Arts et al. 2006; IARC 2006; McGregor et al. 2006).

The lack of distant effects of FA is supported by two observations. First, FA is an endogenous metabolite with a blood level of about $2-3 \mathrm{mg} \mathrm{kg}^{-1}$ (IARC 2006). Second, inhalation does not increase the blood FA level. For example, exposure of humans to $1.9 \mathrm{ppm}$ for $40 \mathrm{~min}$ and rats to $14.4 \mathrm{ppm}$ for $2 \mathrm{~h}$ did not increase blood FA levels (Heck and Casanova 2004). Also, exposures of monkeys to $6 \mathrm{ppm}, 6 \mathrm{~h} \mathrm{day}^{-1}, 5$ days week $^{-1}$ for 4 weeks did not increase the blood FA levels (Casanova et al. 1988). A simplified calculation may be used to illustrate that the delivered FA by inhalation is negligible compared with the entire body pool. Thus, assuming $100 \%$ deposition in the airways of inhaled FA $(>95 \%$ is predicted to be retained (IARC 2006)), a 93\% metabolism (Heck and Casanova 2004), an inhalation of $20 \mathrm{~m}^{3}$ day $^{-1}$ in a $70-\mathrm{kg}$ man, and an exposure concentration of $0.1 \mathrm{ppm}$ $\left(0.12 \mathrm{mg} \mathrm{m}^{-3}\right)$, then the delivered dose to the body pool would be $0.168 \mathrm{mg} \mathrm{day}^{-1}$. The delivered amount to the entire body pool corresponds to about $0.1 \%$ of the pool if it is assumed that the concentration in the blood compartment (about 2-3 $\mathrm{mg} \mathrm{kg}^{-1}$ (IARC 2006)) is equal to the concentration in the entire body $\left(\sim 175 \mathrm{mg}=2.5 \mathrm{mg} \mathrm{kg}^{-1} \times\right.$ $70 \mathrm{~kg}$ ). The contribution to the body pool neglects that FA is metabolized rapidly in the blood compartment as the half-life in rat plasma is about $1 \mathrm{~min}$ (McGregor et al. 2006). Also and more important, a toxicokinetic model predicted that FA is metabolised rapidly by nasal tissue and does not significantly increase the FA blood concentration (Franks 2005).

Implications of DNA-protein cross-links

DNA-protein cross-links can be induced by several agents, e.g. ultraviolet light, ionizing radiation, chromium, nickel and arsenic compounds as well as cisplatin, melphalan, mitomycin C and aldehydes. DPX are considered to affect replication, transcription and repair processes. They may result in mutagenesis or carcinogenesis (Barker et al. 2005), which are well established for FA (IARC 2006). DPX induced by different chemicals have different chemical stability and ability to be repaired (Barker et al. 2005). Thus, when FA reaches the nuclear DNA, it forms DPX. Incomplete repair of FA-induced DPX can lead to the formation of mutations, in particular chromosome mutations and micronuclei $(\mathrm{MN})$ in proliferating cells (Speit and Schmid 2006).

\section{Repair of DPX cross-links}

In vivo rat studies, FA induced DPX was removed rapidly in nasal tissue. This means that the DPX produced in any single day's exposure should be completely or almost completely removed by the time of the next day's exposure (Casanova et al. 1994). In accordance with this, the risk assessment model by Conolly et al. (2004) used a half-life of the DPX repair of $2 \mathrm{~h}$ (Subramaniam et al. 2007). In a recent in vitro study, primary human nasal epithelial cells were treated with FA for $1 \mathrm{~h}$, which increased the DPX level. After cessation of the FA exposure, DPX decreased and the level was no longer significantly increased after $8 \mathrm{~h}$ and the DPX was completely removed after $24 \mathrm{~h}$ (Speit et al. 2008). This also supports that no DPX accumulation (increasing DPX over time) occurs in vivo at the portal-ofentry epithelial cells. Loss of DPX is considered to be due to spontaneous hydrolysis and active repair processes (Quievryn and Zhitkovich 2000).

\section{Chromosomal effects in nasal and buccal cells}

The primary genotoxic effect of FA is considered to be DPX formation (Liu et al. 2006; Schmid and Speit 2007). In the same concentration range, FA induced chromosome mutations, sister-chromatid exchanges (SCE) and formation of $\mathrm{MN}$ in V79 Chinese hamster cells, but no gene mutation was observed in the HPRT locus (Merk and Speit 1998). Both SCE and MN increased non-linearly with increasing FA level (Merk and Speit 1998) and both showed an apparent NOAEL in the low-exposure range (Merk and Speit 1998; Fig. 5).

Genotoxic effects are considered plausible in nasal and buccal mucosa cells due to the high reactivity of FA. It appears that the most sensitive genetic endpoints for detection of FA mutagenicity are chromosomal aberrations and MN (Speit and Schmid 2006).

A critical review identified eight human studies, reporting frequencies of $\mathrm{MN}$ in nasal and buccal mucosa cells. Two studies, (Kitaeva et al. 1996; Ying et al. 1997), were not considered reliable for methodological reasons (Speit and Schmid 2006). The remaining six studies were inconsistent and had limitations in design, exposure characterization and confounder control (Speit and Schmid 2006). One of the studies showed no increase in $\mathrm{MN}$ in the nasal mucosa; the buccal cell effect was not determined. A study in a plywood factory showed an increase in MN in nasal cells; buccal cell effect was not determined. We note that wood dust is a potential confounder. Two studies determined both nasal and buccal effects. These studies were from the same embalming course and both showed buccal, but no nasal effect (Suruda et al. 1993; TitenkoHolland et al. 1996).

The Suruda et al. (1993) study is selected as representative as it was the primary study where data was collected. It is a prospective study with 29 mortician students attending an 85-day course in embalming, where exposures were 
to embalming solutions with several volatile compounds, including FA, glutaraldehyde and phenol. Glutaraldehyde exposures were below $0.15 \mathrm{ppm}$ and phenol exposures below $0.1 \mathrm{ppm}$. Each embalming session lasted about $2 \mathrm{~h}$, and the mean FA exposure level was $1.4 \mathrm{ppm}$ (range: $0.15-4.3 \mathrm{ppm}$ ) with peak exposures up to $6.6 \mathrm{ppm}$. The mean 8-h time-weight average FA level was $0.33 \mathrm{ppm}$ on days where embalmings were made. Several of the students had part-time jobs in funeral homes with mean FA exposures about $1 \mathrm{ppm}$ (range: $0.58-3.32 \mathrm{ppm}$ ). During the course, the mean number of embalmings per student were 6.9 (range: 2-15). After the embalming course, a 12-fold increase, which was statistically significant, was seen in the buccal cell MN, whereas a non-significant increase (22\%; $p=0.26$ ) was seen in the nasal MN (Suruda et al. 1993). From the other study, the primary mechanism appeared to be chromosomal breakage (Titenko-Holland et al. 1996).

The Burgaz and co-workers conducted two studies (Speit and Schmid 2006), which showed an increase in MN among FA-exposed subjects in pathology and anatomy laboratories. The first study was devoted to nasal cells and the second study to buccal cells. In the most recent study in the buccal mucosa cells, the mean exposures were up to 4 ppm FA obtained by stationary sampling (Burgaz et al. 2002). We note that stationary sampling may underestimate the personal exposure.

Another study was also evaluated by Speit and Schmid (2006). Three groups of non-smokers, 18 workers in an FA-producing factory, 16 waiters exposed to FA from building materials, furniture and environmental tobacco smoke, and 23 controls (undergraduate students) were investigated for $\mathrm{MN}$ in the nasal mucosa cells. The 8-h time-weighted average FA level was $1,0.1$ and $0.01 \mathrm{mg} \mathrm{m}^{-3}$, respectively, with maximum levels of 1.7 , 0.3 and $0.015 \mathrm{mg} \mathrm{m}^{-3}$. The MN formation was significantly increased in the workers, but not in the waiters (Ye et al. 2005).

A recent controlled study, performed under GLP-like conditions, had FA concentrations that were relevant for evaluation of indoor air effects (Speit et al. 2007). Twentyone volunteers were exposed to $0.15-0.5 \mathrm{ppm}$ FA with 15 min peaks at 0.6 and $1 \mathrm{ppm}$, respectively. Exposures were for $4 \mathrm{~h} \mathrm{day}^{-1}$ for 8 days during a 10-day period. No significant increase was detected in the frequency of $\mathrm{MN}$ in exfoliated buccal mucosa cells.

In conclusion, FA is mutagenic in vivo in nasal and buccal mucosa cells evaluated from MN formation, which is a sensitive endpoint (Merk and Speit 1998). Nevertheless, the interpretation of the studies is difficult due to lack of consistency across studies, incomplete information on study design, exposure and confounding factors in general (Speit and Schmid 2006). Overall, if the observed mutagenic effects are FA dependent, the data suggest that effects are at high mean or high peak exposure concentrations, and no effect is expected at exposures somewhat above normal indoor air levels.

\section{Chromosomal effects in peripheral lymphocytes}

Portal-of-entry effects on lymphatic tissue cells could be possible as the upper airways are richly furnished with lymphatic tissue (Kuper et al. 2003; Pohunek 2004). Thus, FA effects on the nasopharyngeal lymphoid tissue (NALT) and the upper respiratory tract draining (superficial cervical and posterior cervical) lymph nodes were studied in mice and rats with FA exposures at $0.5,1,2,6,10$ or $15 \mathrm{ppm}$ for $6 \mathrm{~h} \mathrm{day}^{-1}, 5$ days week $^{-1}$ for 4 weeks. Exposure-dependent effects were limited to the $15 \mathrm{ppm}$ group in rats, where NALT showed hyperplasia and germinal centers were absent in the superficial cervical lymph nodes. Also, an increased proliferation of the NALT lymphoepithelium was observed (Kuper et al. 2010). It is suggested on the basis of the lack of effect in mice and effects in rats were observed only at the highest exposure level that an FA effect on local lymphatic tissue should be limited to high exposure levels.

Several human biomonitoring studies have shown induction of DPX, SCE, chromosome aberrations and MN in blood cell cultures. FA-induced DPX is considered the primary DNA lesion (Speit and Merk 2002; Liu et al. 2006; Schmid and Speit 2007), and the mutagenic effect is due to chromosomal aberration by a clastogenic mechanism, but not due to point mutations (Speit and Merk 2002). In human peripheral blood lymphocytes, DPX has a long half-life due to inefficient repair processes and DPX is mainly removed by spontaneous hydrolysis. The presence of active DNA repair in these cells may not be biologically important as lymphocytes are terminally differentiated cells and because there is no danger of converting DNA lesions into mutations (Quievryn and Zhitkovich 2000). The DPX formation in lymphocyte cultures was non-linear and DPX levels at low FA doses were apparently similar to DPX in the control lymphocytes not exposed to FA (Liu et al. 2006, Fig. 1). Low-dose FA-induced DPX was completely removed before lymphocytes started to replicate. Cytotoxic effects occurred in parallel or even preceded SCE formation. Formation of MN occurred only if cytotoxicity was present and only at a certain time-window. Both SCE and MN formation were non-linearly related to FA exposure and apparently showed NOAEL (Schmid and Speit 2007; Figs. 4A, 7A). The authors concluded that systemic genotoxic effects of FA lack plausibility, supported by the majority of the rat studies (Kligerman et al. 1984; Speit et al. 2009 and references therein) at exposures up to $15 \mathrm{ppm}$ in 4 weeks. 
Peripheral lymphocyte effects may comprise not only DPX, but also DNA-DNA crosslinks that may appear at a slightly lower concentration, and DNA single-stranded breaks that may occur at an even lower concentration (Liu et al. 2006). DNA single-stranded breaks are rapidly repaired such as in Hela cells, where they were repaired 30-40 times faster than DPX as observed from Liu et al. (2006). The single-stranded breaks may become a doublestranded break following DNA synthesis, leading to production of an acentric fragment which would then be expressed as an MN within one division cycle (Fenech 1997); this indicates that cytogenetic assays must investigate several genotoxic mechanisms.

In studies of biomarkers of FA effects in humans, DPX was elevated in FA exposed staff members in hospital pathology departments, where FA exposures were about 3 ppm during work (Shaham et al. 1996, 1997) or in the range from 0.04 to $5.6 \mathrm{ppm}$ (Shaham et al. 2003). The first two studies, considered pilot studies (Shaham et al. 2003), each comprised 12 exposed subjects. The last and most comprehensive of the studies comprised 186 exposed and 213 unexposed staff members (Shaham et al. 2003), where exposures were divided into a low (mean: $0.4 \mathrm{ppm}$ (range: 0.04-0.7)) and a high level (2.24 ppm (0.72-5.6)). The DPX formation was expressed as the fraction of total DNA, which was $0.14,0.19$ and 0.20 in the controls, the low and the high exposed group, respectively. Since FA-dependent DPX is well established to be exposure dependent in vitro and in other in vivo studies, the absence of exposuredependent effects at mean concentrations from 0.4 to $2.24 \mathrm{ppm}$ is inexplicable.

Cytogenetic studies in peripheral lymphocytes in FA-exposed individuals are listed in Table 2. The studies are limited to publications in English, although a few studies in other languages were retrieved but not included. This is not considered to influence a generalization as the majority of all studied and the recent studies are included. Additionally, if a research group has published more studies on the same topic only one study is included. It was apparent from the meta-analyses of cancer hazards that different occupations with FA exposures had different associations with malignancies. This may be due to different exposure levels of FA or different exposures to confounders. Thus, similar types of exposures are divided in groups (Table 2). Smoking was the only confounder that was available from most studies.

Most studies suffer from a low number of exposed individuals and are therefore not considered to be robust. Workers in the carpet and the plastic ware plants were exposed to several airborne compounds in addition to FA (Lazutka et al. 1999). Also, it is questionable whether the exposure assessment is robust. This study is therefore not useful for establishing exposure-response relationships.
Only one study (Ye et al. 2005) consisted of a group (waitresses) with low mean and low peak exposures at indoor air levels. This group showed no cytogenetic effect, but due to the short exposures and the low number of subjects, this study cannot be used for establishing exposure-response relationships. Exposures were high in all studies that showed cytogenetic effects. Thus, in the pathology and anatomy laboratories, the mean exposure range across studies was $<0.1$ to $6.4 \mathrm{ppm}$ and the range of the peak exposures was 0.1 to $20 \mathrm{ppm}$. Students participating in an anatomy laboratory course had mean exposures in the range from 0.4 to $2.4 \mathrm{ppm}$. Mortician students had a mean exposure of about $1.4 \mathrm{ppm}$ during embalming with peaks up to about $6 \mathrm{ppm}$. The industrial exposures were generally below $1 \mathrm{ppm}$ in mean with peaks above $1 \mathrm{ppm}$. This suggests that high mean exposures and high peak levels may drive cytogenetic responses if they are considered to be FA induced. This interpretation has biological plausibility, because high exposure levels can overwhelm detoxification mechanisms.

Overall, there is a strong contrast between the generally negative findings in animal studies and a recent well-conducted in vitro study (Schmid and Speit 2007) compared with the studies reported in Table 2. This may be due either to an inappropriate confounder control or to high FA exposure levels driving the cytogenetic responses. Due to the serious limitations, the human studies cannot be used to establish exposure-response relationships. However, the human studies roughly suggest that mean and peak exposures should be below $1 \mathrm{ppm}$, which comply with the NOAEL for nasal pathologic effects in rats. Thus, risk characterization based on nasal effects in rats is considered to protect against chromosomal effects in peripheral lymphocytes in humans.

\section{Exposure-response relationships for cytotoxicity and squamous cell carcinoma in airborne exposed rats}

The mucosal effect in Wistar rats was studied at exposures to $0,0.1,1$ or 10 ppm FA, $6 \mathrm{~h} \mathrm{day}^{-1}, 5$ days week $^{-1}$ for 1 year (Appelman et al. 1988) and 28 months (Woutersen et al. 1989). No histological effect was apparent at $1 \mathrm{ppm}$. The nasal effects of FA were studied in Fischer 344 rats and Cynomolgus monkeys at $0,0.19,1.0$ or $3.0 \mathrm{ppm}$ for $22 \mathrm{~h} \mathrm{day}^{-1}, 7$ days week $^{-1}$ for 26 weeks (Rusch et al. 1983). In both species, nasal hyperplasia and squamous metaplasia were observed at $3.0 \mathrm{ppm}$, whereas no effect was observed by light and electron microscopy at $1.0 \mathrm{ppm}$. The $1 \mathrm{ppm}$ level can be considered the NOAEL for cytotoxicity at continuous exposure to FA. In another study, nasal epithelial effects were observed at 2 ppm in Fischer 344 rats exposed for $6 \mathrm{~h} \mathrm{day}^{-1}, 5$ days week $^{-1}$ for 6-24 months 
Table 2 Cytogenetic effects in peripheral blood lymphocytes in formaldehyde (FA) exposed individuals

\begin{tabular}{|c|c|c|c|c|}
\hline Exposure & $\begin{array}{l}\text { Number of participants; } \\
\text { exposed (E), controls } \\
\text { (C) and smokers (S) }\end{array}$ & $\begin{array}{l}\text { Exposure in years, } \\
\text { mean (range) or as } \\
\text { indicated. }\end{array}$ & $\begin{array}{l}\text { Exposure in ppm. } \\
\text { Mean (M) (range) } \\
\text { Peak (P) (range) }\end{array}$ & $\begin{array}{l}\text { Statistically significant outcome } \\
\text { of FA exposures }\end{array}$ \\
\hline $\begin{array}{l}\text { Pathology and } \\
\text { anatomy laboratory }^{\mathrm{a}}\end{array}$ & $\begin{array}{l}\mathrm{E}: 30(\mathrm{~S}: 8) \\
\mathrm{C}: 30(\mathrm{~S}: 7) \\
\text { (matched) }\end{array}$ & $11(0.5-27)$ & $\begin{array}{l}\text { M: } 0.44(0.04-1.58) \\
\text { P: up to } 4.43\end{array}$ & $\begin{array}{l}\text { Increased MN, SCE and DNA damage } \\
\text { (comet assay) }\end{array}$ \\
\hline $\begin{array}{l}\text { Pathology and } \\
\text { anatomy laboratory }\end{array}$ & $\begin{array}{l}\text { E: } 59(\mathrm{~S}: 12) \\
\mathrm{C}: 37(\mathrm{~S}: 9) \\
\text { (matched) }\end{array}$ & $13.2(0.5-34)$ & $\begin{array}{l}\text { M }(8 \text { h): } 0.1(<0.1-0.7) \\
\text { P: } 2(0.1-20)\end{array}$ & $\begin{array}{l}\text { Increased MN from pre to post-shift } \\
\text { due to chromosome loss. No DNA } \\
\text { damage detected }\end{array}$ \\
\hline $\begin{array}{l}\text { Pathology and } \\
\text { anatomy laboratory }\end{array}$ & $\begin{array}{l}\text { E: } 90(\mathrm{~S}: 31) \\
\text { C: } 52(\mathrm{~S}: \sim 24)\end{array}$ & $15.4(1-39)$ & $\begin{array}{l}\text { M: } 0.4(0.04-0.7) \\
\text { P: } 2.2(0.7-5.6)\end{array}$ & $\begin{array}{l}\text { Increase in SCE, but not exposure- } \\
\text { level dependent }\end{array}$ \\
\hline $\begin{array}{l}\text { Pathology and } \\
\text { anatomy laboratory }\end{array}$ & $\begin{array}{l}\text { E: } 6(S: ?) \\
\text { C: } 5 \text { (S:?) }\end{array}$ & $\begin{array}{l}(4-11) \\
2-4 \text { h day }^{-1} \\
2-3 \text { days week } \\
-1\end{array}$ & $\begin{array}{l}\text { M: }(0.9-6.4) \\
\text { P: }(8.0-8.9)\end{array}$ & $\begin{array}{l}\text { No increase in chromosome aberration } \\
\text { and no increase in SCE }\end{array}$ \\
\hline $\begin{array}{l}\text { Students taking } \\
\text { anatomy laboratory } \\
\text { course }^{\mathrm{e}}\end{array}$ & E: 23 non-smokers & $\begin{array}{l}3 \mathrm{~h} \text { three times per } \\
\text { week for } 8 \text { weeks }\end{array}$ & $\begin{array}{l}\text { M: } 0.41 \pm 0.24(\mathrm{SD}) \\
\text { P: } 1.04\end{array}$ & $\begin{array}{l}\text { No increase in SCE and no change in } \\
\text { lymphocyte proliferation comparing } \\
\text { pre and post exposures }\end{array}$ \\
\hline $\begin{array}{l}\text { Students taking } \\
\text { anatomy laboratory } \\
\text { course }^{\mathrm{f}}\end{array}$ & $\begin{array}{l}\text { E: } 13 \text { (S: } 0) \\
\text { C: } 10-13(S: 0)\end{array}$ & $\begin{array}{l}10 \mathrm{~h} \mathrm{week}^{-1} \text { for } \\
12 \text { weeks }\end{array}$ & M: 2.4 & $\begin{array}{l}\text { Increase in MN, SCE and frequency of } \\
\text { chromosome aberrations }\end{array}$ \\
\hline $\begin{array}{l}\text { Students taking } \\
\text { anatomy laboratory } \\
\text { course }^{\mathrm{g}}\end{array}$ & $\begin{array}{l}\text { E: } 30 \\
\text { C: } 30 \text { (matched) }\end{array}$ & $\begin{array}{l}7 \text { h week }^{-1} \text { for } \\
15 \text { months }\end{array}$ & $\mathrm{M}:<1$ & $\begin{array}{l}\text { No increase in chromosomal } \\
\text { aberrations }\end{array}$ \\
\hline $\begin{array}{l}\text { Students taking } \\
\text { anatomy laboratory } \\
\text { course }^{\mathrm{h}}\end{array}$ & E: 8 (S: 0) & $\begin{array}{l}>2 \text { Afternoons/week } \\
\text { for } 10 \text { weeks }\end{array}$ & M: $1.2 \pm 0.8$ during dissection & $\begin{array}{l}\text { Before versus after class evaluation: } \\
\text { Increase in SCE }\end{array}$ \\
\hline $\begin{array}{l}\text { Mortician students } \\
\text { taking embalming } \\
\text { course }^{\mathrm{i}}\end{array}$ & C: 23 (S:6) & 9 weeks & $\begin{array}{l}\text { M: } 1.5 \text { during embalming } \\
\text { P: } 4-14\end{array}$ & $\begin{array}{l}\text { Before versus after course evaluation: } \\
\text { Decreased } \mathrm{O}^{6} \text {-alkylguanine DNA } \\
\text { alkyltransferase activity, but not } \\
\text { exposure-dependent }\end{array}$ \\
\hline $\begin{array}{l}\text { Mortician students } \\
\text { taking embalming } \\
\text { course }^{\mathrm{j}}\end{array}$ & E: 29 (S: 5) & 85-day study period & $\begin{array}{l}\mathrm{M}(8 \mathrm{~h}): 0.33 . \\
\text { During embalming }(2 \mathrm{~h}) \text { : } \\
\text { M: } 1.4(0.15-4.3) \\
\text { P: } 6.6\end{array}$ & $\begin{array}{l}\text { Before versus after course evaluation: } \\
\text { MN increased, whereas SCE } \\
\text { decreased }\end{array}$ \\
\hline $\begin{array}{l}\text { Factory with FA } \\
\text { exposure. }\end{array}$ & E: 18 (S: 0) & $8.5(1-15)$ & $\begin{array}{l}\text { M }(8 \mathrm{~h}): 0.8 \pm 0.23(\mathrm{SD}) \\
\text { P: } 1.4\end{array}$ & Increase in SCE \\
\hline Waitresses $^{\mathrm{k}}$ & C: 23 students (S: 0) & 12 weeks & $\begin{array}{l}\text { M }(8 \mathrm{~h}): 0.09 \pm 0.05 \\
\text { P: } 0.24 \\
\text { M }(8 \mathrm{~h}): 0.008 \pm 0.002 \\
\text { P: } 0.012\end{array}$ & No increase in SCE \\
\hline $\begin{array}{l}\text { Carpet plant } \\
\text { Plastic ware plant }\end{array}$ & $\begin{array}{l}\text { E: } 79(\mathrm{~S}: 39) \\
\text { E: } 97(\mathrm{~S}: 36) \\
\text { C: } 90(\mathrm{~S}: 27)\end{array}$ & $\begin{array}{l}(0.2-21) \\
(0.2-25)\end{array}$ & $\begin{array}{l}\mathrm{M}:(\sim 0.24-1.0) \\
\mathrm{M}:(\sim 0.4-0.73)\end{array}$ & $\begin{array}{l}\text { Both plants showed increased } \\
\text { chromosomal aberrations, but } \\
\text { independent of the exposure length }\end{array}$ \\
\hline Paper factory ${ }^{\mathrm{m}}$ & $\begin{array}{l}\text { E: } 20(S: 6) \\
\text { C: } 20(S: 13)\end{array}$ & $14.5(2-30)$ & $\begin{array}{l}\text { Outside the } \\
\text { papermachine } \sim 0.2 \\
\mathrm{P}: \leq 3 \\
\text { Where FA was } 20-50, \text { masks } \\
\text { and protective clothes were } \\
\text { worn. }\end{array}$ & $\begin{array}{l}\text { Increased incidence of dicentrics or } \\
\text { dicentrics and ring chromosomes. } \\
\text { No increase in SCE. }\end{array}$ \\
\hline
\end{tabular}


Table 2 continued

\begin{tabular}{|c|c|c|c|c|}
\hline Exposure & $\begin{array}{l}\text { Number of participants; } \\
\text { exposed (E), controls } \\
\text { (C) and smokers (S) }\end{array}$ & $\begin{array}{l}\text { Exposure in years, } \\
\text { mean (range) or as } \\
\text { indicated. }\end{array}$ & $\begin{array}{l}\text { Exposure in ppm.Mean }(\mathrm{M}) \\
\text { (range)Peak }(\mathrm{P}) \text { (range) }\end{array}$ & $\begin{array}{l}\text { Statistically significant outcome } \\
\text { of FA exposures }\end{array}$ \\
\hline $\begin{array}{l}\text { FA manufacturing } \\
\text { and processing }^{\mathrm{n}}\end{array}$ & $\begin{array}{l}\text { E: } 15 \\
\text { C: } 15 \\
\text { (matched: age and sex) } \\
\text { (S: ?) }\end{array}$ & $28(23-35)$ & $\begin{array}{l}\text { After } 1971) \leq 1 \\
\text { Before } 1971 \leq 5\end{array}$ & $\begin{array}{l}\text { Numerically the frequency of aberrant } \\
\text { metaphases was lowest in exposed } \\
\text { workers }\end{array}$ \\
\hline \multicolumn{5}{|c|}{ a Costa et al. (2008) } \\
\hline \multicolumn{5}{|c|}{ b Orsière et al. (2006) } \\
\hline \multicolumn{5}{|c|}{ c Shaham et al. (2002) } \\
\hline \multicolumn{5}{|c|}{ d Thomson et al. (1984) } \\
\hline \multicolumn{5}{|c|}{ e Ying et al. (1999) } \\
\hline \multicolumn{5}{|c|}{${ }^{\mathrm{f}} \mathrm{He}$ et al. (1998). No details on exposure characterization } \\
\hline \multicolumn{5}{|c|}{ g Vasudeva and Anand (1996). No detail on exposure characterization } \\
\hline \multicolumn{5}{|c|}{ h Yager et al. (1986) } \\
\hline \multicolumn{5}{|c|}{ i Hayes et al. (1997) } \\
\hline \multicolumn{5}{|c|}{ j Suruda et al. (1993) } \\
\hline \multicolumn{5}{|c|}{ k Ye et al. (2005) } \\
\hline \multicolumn{5}{|c|}{$\begin{array}{l}{ }^{1} \text { Lazutka et al. (1999). Approximate area concentrations were from the hygienic control services. Additional exposures were to styrene and } \\
\text { phenol, which were } \sim 0.13-1.4 \text { and } 0.3 \mathrm{mg} \mathrm{m}^{-3} \text {, respectively, in the carpet plant and } \sim 4.4-6.2 \text { and } 0.5-0.75 \mathrm{mg} \mathrm{m}^{-3} \text {, respectively, in the } \\
\text { plastic ware plant }\end{array}$} \\
\hline \multicolumn{5}{|c|}{${ }^{\mathrm{m}}$ Bauchinger and Schmid (1985) } \\
\hline${ }^{\mathrm{n}}$ Fleig et al. (1982) & & & & \\
\hline
\end{tabular}

(Kerns et al. 1983). This indicates that the concentration of FA may be more important for cytotoxicity than the total daily dose (Rusch et al. 1983) and substantiated from calculation of the daily exposure-doses. The NOAEL level of $1 \mathrm{ppm}$ was independent of the length of the daily exposure periods and thus the daily exposure-doses $(1 \mathrm{ppm} \times 6 \mathrm{~h}$ and $1 \mathrm{ppm} \times 22 \mathrm{~h}$, respectively), whereas the slightly higher 2 ppm concentration caused nasal pathological changes although the daily dose, $2 \mathrm{ppm} \times 6 \mathrm{~h}$, was within the dose range that caused no effect if the exposure level was $1 \mathrm{ppm}$.

Formaldehyde caused mainly nasal SCC in rats. A small number of benign tumors (polypoid adenomas) were also observed (Kerns et al. 1983; Monticello et al. 1996). Rats were more sensitive to FA-induced nasal neoplasms than mice (Kerns et al. 1983) and Syrian golden hamsters (Dalbey 1982). In the exposure range from 6 to $15 \mathrm{ppm}$, the time-to-tumor appearance decreased with increasing exposure concentration (Monticello et al. 1996), i.e. lower concentrations require longer exposures for development of tumors. Apparently, the NOAEL for development of SCC was 2 ppm (Monticello et al. 1996), which is also suggested from Table 1. The table also shows a clear nonlinear relationship between FA exposure and development of SCC in the rats.

The Woutersen et al. (1989) study did not show an exposure-dependent development of SCC in Wistar rats, which were exposed up to $10 \mathrm{ppm}$ FA for 28 months (Table 1). The few animals with SCC in the different groups agree with the incidence of SCC in the control groups from another study by the same group (Feron et al. 1988). In that study, three unexposed groups of rats were kept for 117 to 126 weeks and the respective incidences of SCC were 0/44, 2/45 (4.4\%) and 0/45. In the Woutersen et al. (1989) study, an SCC incidence of about $4 \%$ in an exposed group is within the range of SCC in non-exposed rats. The used rats may be less sensitive (Woutersen et al. 1989) than Fischer 344 and Sprague-Dawley rats (Table 1), which show a positive response. Nevertheless, the Wistar rats were able to respond by developing nasal SCC. Nasal damage was induced by electrocoagulation which initiated repair processes and wound healing. Where the nasal damage preceded the FA exposures, many cases of SCC $(15 / 58$; $26 \%$ ) were observed in the 10-ppm group, but no exposure-dependent effect appeared at lower exposures as seen from the SCC incidences in the control group $(1 / 54 ; 1.9 \%)$, the $0.1 \mathrm{ppm}$ group $(1 / 58 ; 1.7 \%)$ and the $1 \mathrm{ppm}$ group $(0 / 56 ; 0 \%)$. These findings indicate that damage-induced cell proliferation is a key mechanism in FA-induced nasal SCC in rats (Woutersen et al. 1989) and that $\leq 1$ ppm FA were not able to induce SCC even with increased cell proliferation. 
The NOAEL (1 ppm) for nasal cytotoxic effects, the NOAEL ( 2 ppm) for development of SCC and the importance of damage-induced cell proliferation have been used in the risk characterization.

\section{Exposure-response relationships for lymphohematopoietic malignancies in animals}

\section{Drinking water studies}

FA was administered in the drinking water in a 2-year study in Wistar rats (Til et al. 1989). Males were dosed with $0,1.2,15$ or $82 \mathrm{mg} \mathrm{kg}^{-1} \mathrm{day}^{-1}$ and females with 0 , $1.8,21$ or $109 \mathrm{mg} \mathrm{kg}^{-1} \mathrm{day}^{-1}$. Each group comprised 50 rats of each gender. Treatment-related pathological effects were limited to changes in the stomach and the kidney in both genders in the high-dose group; the kidney effect was considered secondary to the decreased intake of liquid. The incidences of tumors did not vary markedly between the groups. Thus, the number of tumor-bearing rats as well as the total number of tumors were lower in the high-dose males than in the control males. Hematological tumors were limited to generalized histocytic sarcoma in one male and myeloid leukemia in another male, both in the highdose group. Additionally, no lymphoma appeared in the high-dose group and no exposure-dependent lymphoma appeared from the study of the axillary lymph nodes and the small intestine.

In another study (Tobe et al. 1989), FA was administered for up to 24 months in Wistar rats. Exposure levels were $0,10,50$ or $300 \mathrm{mg} \mathrm{kg}^{-1} \mathrm{day}^{-1}$. Each group consisted of 20 rats of each gender. None of the animals survived 24 months of exposure in the $300 \mathrm{mg} \mathrm{kg}^{-1}$ day $^{-1}$ group and severe lesions were observed in the stomach. Additionally, serum urea nitrogen increased significantly in both genders, suggesting an effect on the kidney. It was reported that there was no significant difference in any tumor incidence among the groups.

In a 104-week study (Soffritti et al. 2002), SpragueDawley rats were exposed to $10,50,100,500,1000$ or $1500 \mathrm{mg} \mathrm{FA} ~^{-1}$ drinking water. An additional group was treated with $15 \mathrm{mg}$ methanol $\mathrm{l}^{-1}$. The treated groups consisted of 50 males and 50 females. The tap water control group consisted of 100 males and 100 females. Animals were observed until they died spontaneously. There was no difference in survival in the groups. However, the number of tumor-bearing animals increased significantly in the highest exposure group in males. In females, the incidence of malignant mammary gland tumors increased significantly in the highest FA-exposed group. In the female control, methanol, 10, 50, 100, 500, 1000 and $1500 \mathrm{FA} \mathrm{l}^{-1}$ groups, the percentage of animals with hemolymphoreticular neoplasia was $7,10,10,14,16,14,22 *$ and $20 \% *$, respectively. In the males, the percentage was $8,20,8,20,26^{* *}$, $24 *, 22 *$ and $46 \% * *$, respectively. The level of significance was $p<0.05(*)$ and $p<0.01(* *)$, respectively. The study has a number of limitations (IARC 2006). This applies to the "pooling" of lymphomas and leukemias ("hemolymphoreticular neoplasia"), the lack of reporting of non-neoplastic lesions, and the absence of information on incidence of hemolymphoreticular tumors in the historical controls. Also, the incidence in comparison with the methanol-treated group was significantly increased only in the high-dose males, but the dose-response relationship was still statistically significant. Additionally, a surprising discrepancy was observed. In a preliminary report of the study, it was stated that 79 animals had hemolymphoreticular malignancies, whereas it was stated in the final report that 150 animals had these malignancies.

Overall, the drinking water studies showed no increase in lymphohematopoietic malignancies in two well-conducted studies. Where significant, the effects were at the high FA levels and apparently, exposure-response relationships were non-linear. However, these results were from a study with severe limitations.

\section{Inhalation studies}

Several long-term studies have been conducted in different species, including hamsters (Dalbey 1982) and rats (Feron et al. 1988; Woutersen et al. 1989; Monticello et al. 1996). They do not report lymphohematopoietic malignancies with FA exposures from 0.1 to $20 \mathrm{ppm}$. If lymphohematopoietic malignancies were frequently occurring diseases, their discovery would have been anticipated. If they are less frequent than nasal cancer after FA exposure, they may have been considered incidental findings and not reported. However, three studies allow the possibility to be addressed.

In an inhalation study, groups of approximately 120 male and 120 female Fischer 344 rats and C57BL/6 $\times \mathrm{C}^{2} \mathrm{HF}_{1}$ mice were exposed to $0,2.0,5.6$ or 14.3 ppm FA $6 \mathrm{~h} \mathrm{day}^{-1}$, 5 days week $^{-1}$, for 24 months. The exposure period was followed by up to 6 months of non-exposure. Gross pathological examinations were performed on all animals that died or were sacrificed; histopathology was performed on 50 tissues per animal in the control and the high exposed group. A significant increased mortality was observed both in male and female rats in the high-dose group and in males in the intermediate group. Survival in female mice was not affected by FA exposures. Exposed male mice had a slightly poorer survival, but this was not statistically significant. The significant FA-induced lesions were restricted to the nasal cavity and proximal trachea in both species (Kerns et al. 1983). 
The slides from the Kerns et al. (1983) study were re-evaluated by Woutersen (2007) for investigation of occurrence of lymphohematopoietic malignancies. Additionally, to take into account that early death due to nasal cancer may limit the detection of lymphohematopoietic malignancies, a mortality adjusted trend test was used (the Peto Mortality-Prevalence test) for evaluation where exposed groups showed differences in survival. In the rats, neither at the end of the 24-month exposure period nor in the 6-month recovery period were there any association between FA exposure and leukemia in the male and female rats. At the end of the 24-month exposure period, lymphoma was rare in male mice. The occurrence was 1 , 1,1 , and $0 \%$, respectively, in the $0,2.0,5.6$ and $14.3 \mathrm{ppm}$ FA exposure groups. In contrast, the trend was highly significant in the female mice, where the occurrence of lymphoma was 17, 16, 9 and $29 \%$, respectively. The trend was no longer significant in mice allowed an additional 3 -month recovery period, where the occurrence of lymphoma was 50, 20, 15 and $45 \%$, respectively. It was concluded that FA may induce lymphoma in female mice, which was clearly driven by the incidence in the topexposure group. This re-evaluation allows two conclusions. First, leukemia was not observed in Fischer 344 rats at 24 months of exposure to $14.3 \mathrm{ppm}$, where a high incidence of nasal tumors occurred. Secondly, if lymphoma may be induced by FA in mice, the occurrence is at the very high exposure level, where nasal tumors showed a high incidence in rats.

In another study with 100 Sprague-Dawley rats, the

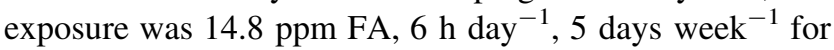
lifelong exposure. Complete necropsy was performed on each animal. Histological sections were performed from each lobe of the lung, trachea, larynx, liver, kidney, testes and other organs, where gross pathology was present. There was an increased mortality in the FA group compared with the control group. In the FA group, three malignant lymphomas were observed. In the similar air control group of 99 rats, two malignant lymphomas were observed, whereas three were observed in 99 colony controls (Sellakumar et al. 1985).

In a 28-month study, male F-344 rats in groups of 32 were exposed to FA for $6 \mathrm{~h} \mathrm{day}^{-1}, 5$ days week $^{-1}$ at 0 , $0.3,2$ or $15 \mathrm{ppm}$. Additionally, a room control group was included. The number of rats alive at 18 months or later and thus available for histopathology was 19 (0 ppm), 22, 17, 7 and 16 (room control), respectively. Hematological, biochemical and pathological examinations were performed. Tissues for histopathology were pituitary, thyroid, nasal region, trachea, esophagus, stomach, small and large intestine, prostate gland, urinary bladder, muscle, femur, sciatic nerve, spinal cord, mesenteric lymph nodes, and any other gross lesion. Increased mortality was observed at the highest exposure concentration. No microscopic lesions were attributed to FA exposures except these in the nasal cavity. Also, there was no exposure-related abnormal hematological finding (Kamata et al. 1997).

Overall, the occurrence of lymphohematopoietic malignancies in inhalation studies in rats and mice is not convincing. An indication of such an association was only seen in female mice at the highest exposure level, which caused a high incidence of nasal cancer in rats. Also, the exposure-response relationship seems to be non-linear.

\section{Cancer hazards from recent meta-analyses}

Oral cavity and pharynx, sinus and nasal cavity, and lungs

Bosetti et al. (2008) conducted meta-analyses based on six cohorts of industrial workers and six professionals (pathologists, anatomists, and embalmers and funeral directors). No significant excess cancer risk was found in industrial workers and professionals for all cancers, and for oral and pharyngeal cancer. The lung cancer risk was not affected in the industrial workers (relative risk (RR (95\% $\mathrm{CI})$ ): $1.06(0.92-1.23)$ ), whereas the risk was reduced in the professionals $(0.63(0.47-0.84))$. The study concluded that there was no considerable risk for cancer of the oral cavity and pharynx, sinus and nasal cavity, and lungs. The IARC (2006) also concluded that the overall balance of epidemiological evidence did not support a causal role for FA in cancer in the oral cavity, oro and hypopharynx and lungs.

\section{Nasopharyngeal cancer}

In the meta-analysis, the nasopharyngeal cancer risk was increased in FA-exposed industrial workers, but this was not statistically significant (RR (95\% CI): $1.33(0.69$ 2.56)) (Bosetti et al. 2008). The increase was based on eight cancers in one study where six cancers were found in one of ten plants. If the plant with the six cases was excluded from the meta-analysis, the RR was reduced to 0.49 in the pooled estimate (Bosetti et al. 2008). Further discussion of the implication of the cluster with the six deaths in one plant is included in the following paragraphs.

\section{Brain cancer}

No excess brain cancer risk was apparent in industrial workers $(0.92(0.75-1.13))$, but in the meta-analysis, the risk was significantly increased in the professionals (1.56 (1.24-1.96)) (Bosetti et al. 2008). The brain cancer risk was not consistent across the two types of occupation, and it is not biologically plausible that FA causes brain cancer. 
This conclusion agrees with the IARC (2006) evaluation and is further supported from the recent study in embalmers (Hauptmann et al. 2009).

\section{Pancreatic cancer}

In a meta-analysis, the RR was 0.8 (95\% CI: $0.5-1.0)$ based on five populations exposed to FA (Ojajärvi et al. 2000). Pancreatic cancer was also addressed in a meta-analysis which comprised 14 epidemiological studies (Collins et al. 2001). The overall RR was $1.1(1.0-1.2)$. The $R R$ in industrial workers was $0.9(0.8-1.1)$, in embalmers 1.3 (1.0-1.6), and in pathologists and anatomists $1.3(1.0-1.7)$. The authors suggested that there was no relationship between pancreatic cancer and FA exposures. This conclusion agrees with the IARC (2006) evaluation.

\section{Leukemia}

Leukemia was studied in a meta-analysis comprising 18 epidemiological studies (Collins and Lineker 2004). Heterogeneity was observed across studies and differences between RRs of FA exposures in US (1.2 (1.0-1.4)) and European workers $(0.9(0.7-1.1))$ appeared. Furthermore, the RRs were different for various types of job: industrial workers $(0.9(0.8-1.0))$, embalmers (1.6 (1.2-2.0), and pathologists and anatomists (1.4 (1.0-1.9)). This study concluded that the data does not provide consistent support for a relationship between FA exposure and leukemia.

In the meta-analysis by Bosetti et al. (2008), a significantly decreased risk of lymphatic and hemopoietic cancer was observed in industrial workers $(0.85$ (0.74-0.96). In contrast, the risk was significantly increased in professionals (1.31 (1.16-1.47)), comprising pathologists, anatomists and embalmers. No excess in leukemia risk appeared in industrial workers $(0.90(0.75-1.07))$, but the risk was significantly increased $(1.39(1.15-1.68))$ in the professionals. For further discussion, see the following paragraphs.

A recent meta-analysis evaluated especially myeloid leukemia from the highest exposure group of each study (Zhang et al. 2009). Where several RRs were reported in a study, one RR was selected from each study according to peak exposure, average exposure intensity, cumulative exposure and exposure duration. For example, the accepted study groups were exposed to more than $2 \mathrm{ppm}$ on average, having peak exposures above $4 \mathrm{ppm}$ or were exposed for more than 10 years. The meta-analyses by Zhang et al. (2009), Bosetti et al. (2008) and Collins and Lineker (2004) have seven common studies where the sums of the accepted number of leukemia cases were 69, 161 and 197, respectively. In the analysis by Zhang et al. (2009), the fixed effect model and the random effect model showed similar results-in the fixed effect model, the variability of the results is estimated from within-study variations, while the random effect model assumes a different underlying effect for each study, taking into account between-study as well as within-study variations (Khoshdel et al. 2006). As the models gave similar results, no heterogeneity was revealed and results (RR $(95 \% \mathrm{CI}) ; N=$ number of studies included) are from the fixed effect model. An increased risk was observed for all types of cancer combined (1.25 (1.12-1.39); 19), for all leukemia (1.54 (1.24-1.91); 15), for myeloid leukemia (1.90 (1.41-2.55); 6) and for multiple myeloma (1.31 (1.02-1.67); 9), but not for Hodgkin lymphoma (1.23 (0.67-2.29); 8) and non-Hodgkin lymphoma (1.08 (0.86-1.35); 11).

The most recent meta-analysis that includes all relevant cohort and case-control studies published through May 2009 found no increase in leukemias. The meta-analysis summary RR was 1.05 (95\% CI: 0.93-1.20) for cohort studies and the summary OR was $0.99(0.71-1.37)$ for case-control studies. Further, the study concludes that the Zhang et al. (2009) analysis is affected by several limitations that may lead to invalidation of the results (Bachand et al. 2010).

The different results in the meta-analyses are, at least partly, due to different study populations with different exposures. None of the analyses establish numeric concentration-response relationships, which are mandatory for setting standards or guidelines (Nielsen and Øvrebø 2008). However, the increases in leukemia, myeloid leukemia and multiple myeloma in the Zhang et al. (2009) study were not consistently observed in the other studies (Collins and Lineker 2004; Bosetti et al. 2008; Bachand et al. 2010). This may be explained if accepting that these types of cancer may appear at high FA levels, but apparently not at lower FA levels. However, only four studies (Coggon et al. 2003; Hauptmann et al. 2003, 2009; Pinkerton et al. 2004) evaluated leukemia rates by quantitative exposure levels.

\section{Cancer hazards from occupational cohorts}

To obtain concentration-response relationships for FA exposures based on human experiences, the cancer risk due to FA exposures is reviewed from the three largest and recently updated occupational cohorts identified from the IARC (2006), the FA documentation for setting a healthbased occupational exposure limit by the Scientific Committee on Occupational Exposure Limits (SCOEL 2008), and a recent review (Bosetti et al. 2008). Additionally, the recent update of the US National Cancer Institute cohort is considered (Freeman et al. 2009). The cancer risks from the three cohorts are shown in Table 3. This table is limited to anatomical sites that are directly exposed to airborne FA 
Table 3 Cancer risks from formaldehyde exposures were reviewed on the basis of the three largest and recently updated cohorts

\begin{tabular}{|c|c|c|c|c|c|c|c|c|c|c|c|c|}
\hline Study & \multicolumn{3}{|c|}{ NCI cohort ${ }^{\mathrm{a}}(<1996-1994)$} & $\begin{array}{l}\text { NCI coh } \\
(<1996-2\end{array}$ & $2004)$ & & \multicolumn{3}{|c|}{ UK cohort $(1941-2000)^{\mathrm{a}}$} & \multicolumn{3}{|c|}{$\begin{array}{l}\text { US garment worker cohort } \\
(1955-1998)^{\mathrm{a}}\end{array}$} \\
\hline Exposure (ppm) & \multicolumn{3}{|c|}{$\begin{array}{l}\text { Median average intensity: } \\
0.45 \text { and range: } 0.01-4.25 \text {. } \\
\text { Exposure to } \geq 2 \text { occurred } \\
\text { in } 4.7 \% \text { and } 22.6 \% \text { had } \\
\text { peak exposures at } \geq 4\end{array}$} & & & & \multicolumn{3}{|c|}{ Range: 0.1 to $>2$} & \multicolumn{3}{|c|}{$\begin{array}{l}\text { Geometric mean: } 0.15 \text { and } \\
\text { geometric standard } \\
\text { deviation } 1.90 \text {. Range } \\
0.09-0.2 \text {. Past exposures } \\
\text { may have been } \\
\text { substantially higher }\end{array}$} \\
\hline Risk estimate $^{\mathrm{b}}$ & ICD- $8^{\mathrm{c}}$ & $\mathrm{O} / \mathrm{E}$ & SMR & $\mathrm{ICD}-8^{\mathrm{c}}$ & $\mathrm{O} / \mathrm{E}$ & SMR & ICD-9 ${ }^{c}$ & $\mathrm{O} / \mathrm{E}$ & SMR & ICD-9 $9^{c}$ & $\mathrm{O} / \mathrm{E}$ & SMR \\
\hline All cancers & 140-209 & $1916^{\mathrm{d} /-^{\mathrm{e}}}$ & $0.90 *$ & - & - & $1.07 *$ & $140-208$ & $1511 / 1375.2$ & $1.10 *$ & $140-208$ & 608/- & $0.89^{*}$ \\
\hline Nose and nasal sinuses & 160 & $3 /-$ & 1.19 & - & - & - & 160 & $2 / 2.3$ & 0.87 & 160 & $0 / 0.16$ & - \\
\hline Pharynx & & & & - & - & - & $146-149.1$ & $15 / 9.7$ & 1.55 & $146-149$ & $3 /-$ & 0.64 \\
\hline Nasopharynx & 147 & $8 /-$ & $2.10 *$ & & & & 147 & $1 / 2$ & - & 147 & $0 / 0.96$ & - \\
\hline Larynx & 161 & $23 /-$ & 0.95 & - & - & - & 161 & $14 / 13.1$ & 1.07 & 161 & $3 /-$ & 0.88 \\
\hline Lung & 162 & 641/- & 0.97 & - & - & - & 162 & $594 / 486.8$ & $1.22 *$ & 162 & $147 /-$ & 0.98 \\
\hline Bone & 170 & $7 /-$ & 1.57 & - & - & - & 170 & $6 / 3.5$ & 1.73 & - & & \\
\hline Prostate & 185 & $131 /-$ & 0.90 & - & - & - & 185 & $80 / 99.4$ & 0.80 & 185 & $11 /-$ & 1.58 \\
\hline Hodgkin's disease & 201 & $20 /-$ & 1.26 & 201 & $25 /-$ & 1.42 & 201 & $6 / 8.5$ & 0.70 & 201 & $2 /-$ & 0.55 \\
\hline Non-Hodgkin's lymphoma & $\begin{array}{l}200 \\
\& 202\end{array}$ & $44 /-$ & $0.61 *$ & $\begin{array}{l}200 \\
\& 202\end{array}$ & $94 /-$ & 0.85 & $\begin{array}{l}200 \\
\& 202.0 \\
\& 202.1 \\
\& 202.8\end{array}$ & $31 / 31.7$ & 0.98 & 200 & $5 /-$ & 0.85 \\
\hline Multiple myelomas & 203 & 28/- & 0.88 & 203 & $48 /-$ & 0.94 & 203.0 & $15 / 17.5$ & 0.86 & - & & \\
\hline Leukemia & 204-207 & $65 /-$ & 0.85 & 204-207 & $116 /-$ & 1.02 & 204-208 & $31 / 34.1$ & 0.91 & 204-208 & $24 /-$ & 1.09 \\
\hline Lymphatic leukemia & - & - & - & 204 & $36 /-$ & 1.15 & - & - & - & - & - & - \\
\hline Myeloid leukemia & 205 & $-1-$ & - & 205 & $44 /-$ & 0.90 & & & $0.89^{\mathrm{g}}$ & 205 & $15 /-$ & 1.44 \\
\hline Stomach & - & - & - & - & - & - & 151 & $150 / 114.4$ & $1.31 *$ & 151 & $13 /-$ & 0.80 \\
\hline All digestive & $150-159$ & $420 /-$ & $0.89 *$ & - & - & - & - & - & - & $150-159$ & $116 /-$ & $0.77 *$ \\
\hline
\end{tabular}

The US National Cancer Institute (NCI) cohort comprised 25,619 workers employed in ten US formaldehyde producing or using facilities. Workers were employed prior to 1 January 1966 and were followed-up through 31 December 1994 (Hauptmann et al. 2003 ; Hauptmann et al. 2004) and recently through 31 December 2004 for lymphohematopoietic malignancies (Freeman et al. 2009). A British (UK) cohort from six British factories, comprising 14,014 men employed after 1937 and followed-up through December 2000 (Coggon et al. 2003). The US National Institute for Occupational Safety and Health established a cohort with 11,039 employees in three garment facilities (US garment worker cohort). The study was updated through 31 December 1998 (Pinkerton et al. 2004)

${ }^{a}$ Comparison with national death rates

b Standardized mortality ratio (SMR), observed cases (O), expected cases (E), and the ratio (O/E). When the $95 \%$ CI does not include 1.00 , it is indicated by * and bold

c International Classification of Diseases: 8th revision (ICD-8) and 9th revision (ICD-9)

${ }^{d}$ In the Hauptmann et al. (2003) study, the number of formaldehyde workers who had died was 1,916 (2-year lag interval) and in the Hauptmann et al. (2004), the number was 1,723 (15-year lag interval). The lag interval was 2 years in the Freeman et al. (2009) study

e Not indicated

${ }^{\text {f }}$ Hauptmann et al. 2004 (Table 2) report eight nasopharyngeal cancers among formaldehyde exposed workers that were used for the SMR calculation. Although one subject was misclassified on the death certificate, this subject was retained in the SMR calculation since population reference rates are based on death certificates. Also, the exact $95 \%$ CI was reported to be $0.91-4.14$ and thus the SMR value of 2.10 is not statistically significant. The seven cases in the text and in Tables 3-6 of Hauptmann et al. (2004) were used for calculation of relative risks

g Estimated by Cole and Axten (2004) for the high exposed group ( $>2 \mathrm{ppm}$ )

and to other sites where excess risks have been reported. Cancer effects are exposure-dependent as shown from animal studies (Table 1) and thus potential risks may be characterized more easily from the cohorts with occupational exposures that are much higher than indoor air concentrations.
The US National Cancer Institute (NCI) cohort

Nasopharyngeal cancer

The NCI cohort comprised 25,619 workers employed in ten US FA-producing or using facilities. Workers were 
employed prior to 1 January 1966 and were followed-up through 31 December 1994 and causes of death were obtained for 8,486 deceased cohort members (Hauptmann et al. 2003, 2004). The standardized mortality ratio (SMR) for the different endpoints is shown in Table 3. The SMR was 2.10 for nasopharyngeal cancer in FA-exposed workers, which is remarkable compared with the other SMRs. The 95\% confidence interval (95\% CI: 1.05-4.21) was above one, but the increase was not statistically significant as the exact $95 \%$ CI was from 0.91 to 4.14 (Hauptmann et al. 2004).

The relative risk of nasopharyngeal cancer was further evaluated by four metrics: average exposure intensity (ppm), highest peak exposure (ppm), cumulative exposure (ppm-year) and duration of exposure (year). In the average exposure intensity metric and the highest peak exposure metric, the RR risks were obtained with the unexposed group as the reference group. In the three average exposure intensity exposure groups, $>0$ to $<0.5,0.5$ to $<1.0$ and $\geq 1 \mathrm{ppm}$, the respective RRs were: not obtainable $(0 / 3,640$ death), 0.38 (1/1,405 death) and 1.67 (6/1,450 death). Apparently, the increased risk was due to exposures to $\geq 1$ ppm FA, although the trend was not statistically significant. With the peak exposure metric, all exposed deaths were in the highest peak exposure group ( $\geq 4 \mathrm{ppm}$ ) and the trend was statistically significant. An exposure-dependent trend was also found in the cumulative exposure metric (Hauptmann et al. 2004), which was apparently driven by the highest exposure level. Stratifying into plants, it appeared that the majority of the cases occurred in one plant. Significant exposure trends were apparent for the peak exposure, the cumulated exposure and the duration of exposure metric (Hauptmann et al. 2004). This suggests an FA exposure-dependent effect at high exposure levels.

The Hauptmann et al. (2004) study evaluated 11 potential confounders, including wood dust, which was not found to be a confounder; wood dust is a potential risk factor for nasopharyngeal cancer (Hildesheim et al. 2001; Chang and Adami 2006). Smoking is another potential confounder (Vaughan et al. 2000; Chang and Adami 2006), but as no increase was apparent in smoking-related diseases, smoking was not a likely confounder. Another potential confounder is Asian diet (c.f. Spano et al. 2003; Chang and Adami 2006). It may be important that the FA-associated risk of nasopharyngeal cancer was highest in subjects also infected with Epstein-Barr virus (EBV) (Hildesheim et al. 2001; Chang and Adami 2006). An EBV-encoded RNA signal is present in nearly all nasopharyngeal carcinoma cells (Spano et al. 2003; Wei and Sham 2005). The study did not address this point (Hauptmann et al. 2004). Another potentially important confounder has recently been discovered. In the recent update (Freeman et al. 2009), it was found that 1,006 deaths in the period 1980-1994 were not identified and included in the Hauptmann et al. (2003) and Hauptmann et al. (2004) studies, which were now included in the recent update (Freeman et al. 2009).

From reanalyses of the (Hauptmann et al. 2004) study, it was highlighted that six of the ten nasopharyngeal cancer cases were from one (the Wallingford) plant with all cases among the FA-exposed workers, whereas four cases were from the remaining nine plants, which were divided into two cases in exposed and two in the non-exposed workers (Tarone and McLaughlin 2005; Marsh and Youk 2005). The regional rate-based SMR (95\% CI) was 10.32 (3.7922.47) for FA-exposed workers in the Wallingford plant and $0.65(0.08-2.33)$ in the combined group of FA-exposed workers from the other nine plants. Thus, the exposuredependent effect (Hauptmann et al. 2004, 2005) was driven by the cases in the Wallingford plant (Marsh and Youk 2005). Assuming a causal relationship and that the Wallingford plant had a high FA level, it follows that an FA level exists where no excess nasopharyngeal cancer is observed.

Later, a follow-up study (1945-2003) was conducted in the Wallingford plant, including 7,345 workers and seven (one new) nasopharyngeal cancers (Marsh et al. 2007a). The local county rate-based SMR for nasopharyngeal cancer was 4.43 (1.78-9.13). In their nested case-control study, the nasopharyngeal cancer risk was significantly associated with silver smithing and silver smithing or other metal work. Neither was a significant excess risk nor was a significant trend observed for FA exposure (exposure versus no exposure), duration of exposure, cumulative or average intensity. Further, four of seven cases worked $<1$ year in the Wallingford plant (c.f. Marsh et al. 2007a). Overall, excess nasopharyngeal cancers were considered to be due to metal work and its associated exposures to carcinogenic agents, including strong inorganic-acid mists. However, a limitation of the hypothesis is the lack of objective exposure data for these potential exposures. Additionally, a few cases of nasopharyngeal cancers in the reference group may cause unstable RR estimates (Marsh et al. 2007b), which applies to the NCI study in the average exposure intensity and the peak exposure analysis, where each reference group contained two nasopharyngeal cancers. A similar limitation should apply to the Marsh et al. (2007a) study as the reference groups in several cases have a small number of cases.

An FA-induced development of nasopharyngeal carcinoma in the Hauptmann et al. (2004) study is consistent with the FA-induced development of nasal tumors in rats (Table 1). Epidemiological studies are less clear and show, for example, a significant association (Vaughan et al. 2000), weaker and occasionally significant associations (Hildesheim et al. 2001), and non-significant excesses 
(Hayes et al. 1990; Hansen and Olsen 1995) of nasopharyngeal cancer in FA-exposed persons. The two other cohorts (Table 3) showed no increase in nasopharyngeal cancer. Another potential support for a causal association in humans is the exposure-response relationship, which showed a high risk at high exposures and no risk at low exposures. This corresponds to the non-linear exposureresponse relationship in rats (Table 1) and thus supports the proposal for a NOAEL.

For indoor air guideline setting, it should be taken into account that no excess nasopharyngeal cancer was observed at a mean exposure level of FA at or below $1 \mathrm{ppm}$ and with peak exposures below $4 \mathrm{ppm}$. This is in agreement with a NOAEL for SCC in rats at $2 \mathrm{ppm}$ and lack of histopathologic effect at $1 \mathrm{ppm}$. This similarity is taken into account in the risk characterization.

\section{Lymphohematopoietic malignancies}

The NCI study also evaluated the effect of average intensity and peak exposures for occurrence of lymphohematopoietic malignancies comprising 178 deaths, 17 in unexposed and 161 in exposed workers. The SMR for lymphohematopoietic malignancies (ICD-8: 200-209) was 0.62 (95\% CI: 0.39-1.00) in unexposed workers and 0.80 (0.69-0.94) in exposed workers (Hauptmann et al. 2003). The lowest exposed groups were used as reference for evaluation of RRs. For the average exposure intensity, the reference group comprised exposures from 0.1 to $0.4 \mathrm{ppm}$. The two higher exposure groups comprised exposures from 0.5 to 0.9 and $\geq 1 \mathrm{ppm}$. Lymphohematopoietic malignancies were significantly increased in both groups with a borderline significant trend. Hodgkin's disease was significantly increased in the $0.5-0.9 \mathrm{ppm}$ group with a significant exposure-dependent trend. Myeloid leukemia was significantly increased at the highest exposure level, but the trend was not significant. For the peak exposure, the exposure in the reference group ranged from 0.1 to $1.9 \mathrm{ppm}$ and the exposure in the two higher exposure groups was 2.0-3.9 and $\geq 4$ ppm, respectively. Significantly increased RRs were observed for lymphohematopoietic malignancies and leukemia in the two highest exposure groups. In the highest exposure group, the RR risk for myeloid leukemia was also increased. For these three diseases, the trend in exposure-dependent effect was statistically significant. Additionally, the exposure-dependent trend was statistically significant for Hodgkin's disease. The RR for leukemia was not associated with cumulative exposure.

The Hauptmann et al. (2003) study was reanalyzed by Marsh and Youk (2004). It was shown that excess leukemia and myeloid leukemia were strongly influenced by deficits in death in the reference groups when compared to the US and local county rate-based SMRs. Using the US and local county rate-based SMRs, the SMRs for all leukemia and myeloid leukemia were very close to unity with peak exposures in the range $2.0-3.9 \mathrm{ppm}$ and not significantly increased in the highest peak exposure category ( $\geq 4 \mathrm{ppm}$ ). For evaluation of robustness of the categorizations, new average exposure intensity categories were constructed, where the highest exposure category comprised $\geq 0.74 \mathrm{ppm}$. Again, the use of the US and local county rates showed that the SMRs for all leukemia and myeloid leukemia were close to unity and were not significantly increased. Also in this case, cumulative FA exposures were not associated with the development of leukemia and myeloid leukemia.

Recently, the NCI study updated lymphohematopoietic risks through 31 December 2004 (Freeman et al. 2009). SMRs were estimated from the US mortality rate (Table 3). For lymphohematopoietic malignancies, the 319 deaths resulted in similar SMRs in exposed and unexposed workers (SMR: 0.94 (95\% CI: 0.84-1.06) and 0.86 (0.611.21), respectively). Exposure-dependent trends were evaluated from exposure categories similar to the previous follow-up. For lymphohematopoietic malignancies in the average FA intensity metric, neither of the two highest exposure groups showed an increased RR and nor was the exposure-trend statistically significant. This is in direct contrast to the results from the previous follow-up (Hauptmann et al. 2003). In the new follow-up, the RR for Hodgkin's disease was significantly increased in the $0.5-$ $0.9 \mathrm{ppm}$ group, but not in the highest exposure group ( $\geq 1 \mathrm{ppm})$; the trend was statistically significant. Similar results appeared in the previous follow-up. Multiple myeloma was significantly increased among the non-exposed, but not in the exposed groups. In the previous follow-up, the increase was not significant. In the peak exposure metric, lymphohematopoietic malignancies were increased significantly in the highest exposure group ( $\geq 4 \mathrm{ppm})$ and the trend was significant. Apparently, it is driven by the highest exposure group. Thus, the RR in the next highest exposure group was not remarkably increased (RR $(95 \%$ CI): 1.17 (0.86-1.59)), and close to the RR among the unexposed, which was $1.07(0.7-1.62)$. This is in contrast to the results from the previous follow-up, where the RRs in the two highest exposure groups were similar (1.71 and 1.87, respectively) and significantly increased in both groups. The trend was also significant. In the new followup, the RR of Hodgkin's lymphoma was increased significantly in the two highest exposure groups $(3.30$ (1.04-10.50) in the 2.0-3.9 ppm group and 3.96 (1.3112.02 ) in the $\geq 4 \mathrm{ppm}$ ) with an exposure-dependent trend. In the previous follow-up, only the trend was increased significantly, but the RRs were approximately of the same size as in the recent follow-up. Except for a statistical 
increased RR of multiple myeloma in the non-exposed, no other remarkable RR appeared in the peak exposure group in the new follow-up study. For example, the RRs of multiple myeloma were 2.74 (1.18-6.37) among the nonexposed, 1.0 in the reference group $(>0-1.9 \mathrm{ppm}), 1.65$ (0.79-3.61) in the 2.0-3.9 ppm group, and 2.04 (1.01-4.12) in the highest peak exposure group $(\geq 4 \mathrm{ppm})$ with no exposure-dependent trend. In this case, the RR risks in the exposed groups were lower than in the non-exposed group, which does not support an FA-dependent effect. In the similar peak exposure groups, the RRs of myeloid leukemia were $0.82(0.25-2.67), 1.0,1.30(0.58-2.92)$ and 1.78 $(0.87-3.64)$ with a non-significant trend. This finding is in strong contrast to the results from the previous follow-up study, where myeloid leukemia was significantly increased in the highest exposure group (3.46 (1.27-9.43)) with a highly significant trend $(p \leq 0.009)$, which led to the conclusion that FA may cause myeloid leukemia. The authors of the new follow-up were not able to draw an unequivocal conclusion regarding the possible link between FA exposures and lymphohematopoietic malignancies. The association could be due to chance or be a causal association.

For risk characterization, the only remarkable finding from the two follow-up studies is the excess RR of Hodgkin's lymphoma. In view of the limited consistency between the new and the previous follow-up study in general, the interpretation of the finding is not clear, as mentioned by the authors. It is of notice that the RRs increase abruptly above the exposures in the corresponding reference group (peak exposure: $>0$ to $<2.0 \mathrm{ppm}$ and average intensity: $>0$ to $<0.5 \mathrm{ppm}$ ), whereas the RR in the each reference group and the corresponding non-exposed group was not significantly different.

This indicates that an exposure guideline for FA has to consider that peak exposures should be below 2.0 ppm FA and average exposures should be below $0.5 \mathrm{ppm}$ FA for protection against lymphohematopoietic malignancies in general. This is used in the risk characterization.

\section{The British (UK) cohort}

The UK cohort from six British factories comprised 14,014 men employed after 1937 and followed-up through December 2000 (Coggon et al. 2003). At the end of the follow-up, 5,185 of the men had died. The overall mortality from all cancers was slightly higher than expected from national death rates (SMR: 1.10, 95\% CI: 1.04-1.16) as was the lung cancer (SMR: 1.22, 95\% CI: 1.12-1.32) and the stomach cancer mortality (SMR: $1.31,95 \%$ CI: $1.11-$ 1.54), c.f. Table 3. Lung and stomach cancers were further analyzed using the local mortality rates. Lung cancer was only significantly increased (SMR: 1.28 , 95\% CI: $1.13-$ 1.44) in the highest exposed group where the FA level was higher than $2 \mathrm{ppm}$. No trend was seen at lower levels. For example, the risk in the 0.6-2 ppm FA range was 0.99 (SMR) with $95 \% \mathrm{CI}$ from 0.74 to 1.30 . However, there was a non-significant decrease in the risk of death from lung cancer with duration of high exposure. The risk showed no trend to increase with time since the first exposure. The authors interpreted lung cancer in the highest exposed group to be "rather large to be explained simply by a confounding effect of smoking" which was not taken into account. Using the local mortality rate, stomach cancer was not exposure-dependent and by the authors considered as a less plausible outcome. For setting an indoor air guideline, the key information from this study is that no increase in lung cancer was apparent at FA levels below $2 \mathrm{ppm}$. As this level is above values guiding risk characterization for nasopharyngeal cancer and lymphohematopoietic malignancies, protection against these diseases is also considered to protect against a potential lung cancer effect of FA.

The US National Institute for Occupational Safety and Health (NIOSH) cohort

The US NIOSH established a cohort with 11,039 employees from three garment facilities (The US garment worker cohort). The study was updated through 31 December 1998 where 2,206 of the employees had died. The mortality from all malignant neoplasms was significantly less than expected (SMR: $0.89,95 \%$ CI: $0.82-0.97$ ), as was all digestive neoplasms (SMR: 0.77, 95\% CI: $0.63-$ 0.92); see Table 3 for specific malignancies. Additionally, subgroup analyses were performed. Myeloid leukemia (ICD-9: 205) was significantly increased (13 death, SMR: 1.91) with 20 or more years since first exposure, but the trend was not significant. In addition to underlying cause of death, all causes listed on the death certificates were analyzed using multiple cause mortality. Among workers with both ten or more years of exposure and 20 years or more since the first exposure, multiple cause mortality from leukemia was significantly increased-almost twofold (15 death, SMR: 1.92, 95\% CI: 1.08-3.17). Multiple cause mortality from myeloid leukemia was also significantly increased among this group (eight death, SMR: 2.55, 95\% CI: 1.10-5.03) (Pinkerton et al. 2004). It is noted that the mean time weighted average exposure at the plants in the early 1980s was 0.15 ppm FA but past exposures may have been substantially higher and mortality from myeloid leukemia was highest among workers first exposed in the earliest years. Confounder control was limited to crude adjustment for age in the internal analysis. An industrial hygiene survey conducted at the time of the original study did not identify any chemical exposure at the plants besides FA which had likely influenced the outcome. Smoking was not reported. On the whole, the study can be used for 
qualitative input to the risk characterization, but it does not add reliable information on quantitative exposure-response relationships.

\section{Lymphohematopoietic effects in recent studies}

Other studies have suggested an association between FA exposure and development of lymphohematopietic malignancies (IARC 2006). A proportional mortality study in embalmers in California that comprised 1,007 white males who had died, thus showed a mortality significantly elevated for total cancer (PMR: 121) and for leukemia (PMR: 175) (Walrath and Fraumeni 1984). In a retrospective cohort of 2,317 anatomists in the US, the standardized mortality ration (SMR $(95 \% \mathrm{CI}))$ was marginally and nonsignificantly elevated (1.2 (0.7-2.0), which was mainly due to a non-significant increase in leukemia (1.5 (0.7-2.7)) (Stroup et al. 1986). The causes of mortality among 4,046 male US embalmers and funeral directors, who had died, were investigated in a proportional mortality study. Lymphohematopoietic malignancies (PMR: 139), myeloid leukemia (PMR: 157) and other unspecified leukemia (PMR: 228) were significantly increased (Hayes et al. 1990). On the contrary, in a population-based case-control study in Iowa and Minnesota that included 513 leukemia cases and 1,087 controls, no association was found between leukemia and FA exposure. Thus, in the low exposed FA group, comprising 61 cases, the OR $(95 \% \mathrm{CI})$ was $1.0(0.7-1.4)$ and $0.7(0.2-2.6)$ in the high FA group, comprising three cases (Blair et al. 2000). The lack of exact exposure concentrations is a general limitation of these studies. In contrast, exposure levels were addressed in the two recent studies (Zhang et al. 2010; Hauptmann et al. 2009).

Hematopoietic tissue damage was studied in 43 FA exposed workers, which were compared with 51 controls. The 8-h time-weighted average was 1.57 and 0.032 $\mathrm{mg} \mathrm{m}^{-3}$, respectively, and the 90 percentile 3.09 and $0.032 \mathrm{mg} \mathrm{m}^{-3}$, respectively. Peak exposure concentrations were not reported. FA exposures were associated with reduced blood lymphocyte, granulocyte, platelet, red blood cell and total white blood cell counts. For example, the total white blood cell count was reduced by $13.5 \%$ in the FA-exposed workers. Urinary benzene concentrations were low in both groups, excluding benzene exposure as a confounder. The findings were considered consistent with a bone marrow toxic effect due to FA (it is noted that it is not possible to evaluate whether the hematologic parameters were outside the normal ranges as they were not provided). Peripheral blood cells from FA exposed and controls were cultivated to derive blood myeloid progenitor cells. The colony formation was decreased non-significantly by $20 \%$ in the FA exposed workers that was considered a toxic effect on the myeloid progenitor cells. Blood mononuclear cells from volunteers were cultivated in vitro to derive different lines of progenitor cells. Different FA concentrations were added to the cultures, showing that FA decreased the number of generated colonies from all progenitor cell lines. This demonstrated that FA can inhibit the proliferation of all progenitor cells if the endogenous FA level is increased due to FA exposures. Blood progenitor cells of the myeloid line were derived from ten high exposed workers (8-h time-weighted FA concentration at $2.63 \mathrm{mg} \mathrm{m}^{-3}$ and 90 percentile at $5.09 \mathrm{mg} \mathrm{m}^{-3}$ ) and 12 controls (8-h time-weighted FA concentration at $0.032 \mathrm{mg} \mathrm{m}^{-3}$ and 90 percentile at $0.032 \mathrm{mg} \mathrm{m}^{-3}$ ). FA-exposed workers showed increased monosomy (loss) of chromosome 7 and increase in trisomy of chromosome 8; these chromosome changes are observed in myeloid leukemia and myelodysplastic syndromes (Zhang et al. 2010). It is noted that the study has limitations in relation to risk characterization of FA exposures at indoor air relevant levels. First, the exposures are extremely high and the unreported peak exposure concentrations may have been at extremes. Second, no exposure response relationship was established. Third, the very high exposure concentrations may be expected to cause mucosal damage that may influence both the nasal metabolism and the absorption into the blood compartment; no information is available on the mucosal tissue. Fourth, the in vitro cell culture study is relevant for mechanistic considerations. However, taking into account that no increase in FA has been observed in the blood compartment of humans due to FA exposures that is supported by model calculations at about $2 \mathrm{ppm}$ (similar results were reached if using extrapolations up to $10 \mathrm{ppm}$, but such an extrapolation may not be valid due to the toxic effects on the mucosal membrane at 2 ppm and above), the interpretation in relation to risk characterization is unclear. Fifth, the lowest in vitro tested concentration (100 $\mu \mathrm{mol} \mathrm{FA} ~^{-1}$ ) decreased colony formation in human blood progenitor cells. However, a five times lower concentration $\left(20 \mu \mathrm{mol} \mathrm{FA}{ }^{-1}\right)$ decreased colony formation in the lung epithelial A549 cell line (Speit et al. 2008), suggesting that the observed effects in progenitor cells reflect cytotoxicity under in vitro cell culture conditions in general. Finally, for transparency it would have been desirable that all measured chemical exposures in addition to FA had been reported.

In a US case-control study (Hauptmann et al. 2009), 168 professionals employed in the funeral industry who died from lymphohematopoietic malignancies were compared with 265 deceased matched controls from the same industry. The 8-h time-weighted average FA intensity was about $0.1-0.2 \mathrm{ppm}$, the average FA intensity while embalming was about $1.5-1.8 \mathrm{ppm}$ and peak exposures about 8.1-10.5 ppm. Four cases died from nasopharyngeal 
cancer, but only two had embalmed, OR (95\% CI): 0.1 (0.01-1.2). No increase was observed in lymphoid malignancies (ICD 8 200-204), including Hodgkin lymphoma (0.5 (0.1-2.6)), which was consistently increased in the previous industrial cohort studies (Hauptmann et al. 2003; Freeman et al. 2009). The study observed a specific association with embalming and myeloid leukemia ((ICD 8 205). Thus, using a reference group of never exposed individuals containing one myeloid leukemia subject, the odds ratio (OR $(95 \% \mathrm{CI})$ ) of myeloid leukemia was 11.2 (1.3-95.6) in the FA-exposed individuals.

The first analysis of myeloid leukemia used a reference group of subjects that had not performed embalming. In this reference group, one subject had myeloid leukemia. The duration (years (y)) of working in jobs with embalming showed a significant trend $(p=0.02)$. In the categories $>0-20,>20-34$ and $>34$ years, the odds ratio was 5.0 (0.5-51.6), 12.9 (1.4-117.1) and 13.6 (1.6-119.7), respectively. No significant trend was observed with the number of embalmings. However, several significant ORs were observed. Thus, the number of performed embalmings were divided into $>0-1422,>1422-3068$ and $>3068$ where the OR was $7.6(0.8-73.5), 12.7$ (1.4-116.7) and 12.7 (1.4112.8), respectively. Exposure-response relationships for the different FA metrics were established. The peak exposure metric was the only FA metric that showed a significant trend $(p=0.036)$. Peak FA exposures were divided into $>0-7.0,>7.0-9.3$ and $>9.3 \mathrm{ppm}$ where the OR was 15.2 (1.6-141.6), 8.0 (0.9-74.0), 13.0 (1.4-116.9), respectively. The cumulative FA exposure (ppm-h), average FA intensity (ppm) while embalming, and the 8-h timeweighted average intensity (ppm) showed no FA exposure dependent trend. The cumulative FA exposures (ppm-h) were divided into >0-4058, >4058-9253, and >9253 where the OR was 10.2 (1.1-95.6), 9.4 (1.0-85.7) and 13.2 (1.5-115.4), respectively. The average FA intensity (ppm) while embalming was $>0-1.4,>1.4-1.9$ and $>1.9$ and the OR was 11.1 (1.2-106.3), 14.8 (1.6-136.9) and 9.5 (1.186.0), respectively. The 8-h time-weighted FA intensity (ppm) was divided into $>0-0.10,>0.1-0.18$ and $>0.18$ where the OR was $8.4(0.8-79.3), 13.6(1.5-125.8)$ and 12.0 (1.3-107.4), respectively. It is noted that within each of the FA exposure metrics, the ORs showed little difference and had highly overlapping confidence intervals. This suggests that the statistical significances are driven mainly by exposure versus non-exposure and less by differences in FA exposure levels. Also in each of the FA metrics, none of the trend tests within the FA groups themselves was statistically significant. Additionally, a few cases in a reference group have previously been shown to cause unstable risk estimates (Marsh et al. 2007b).

The second analysis of myeloid leukemia used a reference group in which the subjects performed fewer than 500 lifetime embalmings. It comprised five cases with myeloid leukemia. The duration of working in jobs with embalming showed a significant trend $(p=0.02)$. In the categories $<20,>20-34$ and $>34$ years, the odds ratios were $0.5(0.1-$ 2.9), $3.2(1.0-10.1)$ and 3.9 (1.2-12.5), respectively. No significant trend was observed with the number of embalmings, but significant ORs were observed at the highest exposure level. Thus, the number of performed embalmings were divided into $\geq 500-1422,>1422-3068$ and $>3068$ where the ORs were $1.2(0.3-5.5), 2.9(0.9-9.1)$ and 3.0 (1.0-9.2), respectively. The peak exposure metric was the only FA metric that showed a significant trend $(p=0.036)$ in the FA metrics. Peak FA exposures were divided into $\leq 7.0,>7.0-9.3$ and $>9.3 \mathrm{ppm}$ where the ORs were 2.9 (0.9-9.8), 2.0 (0.6-6.6), 2.9 (0.9-9.5), respectively. The trend was not statistically significant in the cumulative FA exposure, the average FA intensity while embalming or the 8-h time-weighted intensity group. Only the highest cumulative FA exposure group ( $>9,253 \mathrm{ppm}-\mathrm{h})$ had a statistically elevated OR (3.0 (1.0-9.2)). Except for this, the other ORs were elevated (2.0-2.9) and very similar within each of the metrics, but none was significantly increased. Also in each of the FA metrics, none of the trend tests within the FA groups themselves was statistically significant. It is noted that the overall picture was similar to that in the first analysis except for the fact that the ORs decreased by $1 / 3$ in this analysis, where a larger number of case subjects were available in the control group. Only one significant OR appeared in the FA exposure metrics, which was in strong contrast to the ten significantly elevated ORs in the first analysis.

It is noted that there is a lack of exposure-dependent differences in OR within the different FA exposure levels in the different metrics. A lack of exposure-dependent effect could be due either to an inappropriate exposure assessment or to the lack of causality between FA exposure and myeloid leukemia. The method of FA exposure has limitations as the estimates were predicted by means of interviews and mathematical models and were not based on measured exposures. It is mentioned by the authors that the peak model was not validated. On the whole, this study cannot be used for risk assessment as it does not provide a convincing exposure-response relationship.

The comparison of the Zhang et al. (2010) and the Hauptmann et al. (2009) studies shows some differences. The Zhang-study suggests an effect on all progenitor cells resulting in a decrease in the production of lymphocytes, granulocytes, platelets and red blood cells. Similar results were obtained from the in vitro cell cultures with different progenitor cell lines. In the Hauptmann-study, the effect was selective at the myeloid progenitor line. Overall, these studies have very high exposure intensities and thus do not contradict the conclusion that lymphohematopoietic 
malignancies are not observed at lower levels as derived from the Hauptmann et al. (2003) study and its re-analysis by (Marsh and Youk (2004).

\section{Risk characterization}

Lymphohematopoietic malignancies

Lymphohematopoietic malignancies have been reported in human studies with FA exposures. In contrast, long-term inhalation carcinogenicity studies in rats, mice or hamsters were mainly negative or observed as a high-dose phenomenon. This lack of consistency across species (Naya and Nakanishi 2005; Pyatt et al. 2008) weakens the support for a causal relationship. From the reanalysis (Marsh and Youk 2004) of the Hauptmann et al. (2003) study, no excess lymphohematopoietic malignancies was observed with a mean exposure level of FA below $0.74 \mathrm{ppm}$ and peak exposures below $4 \mathrm{ppm}$. Cross-comparison of results from the recent follow-up (Freeman et al. 2009) and the previous follow-up (Hauptmann et al. 2003) showed consistency only for Hodgkin's lymphoma. However, the interpretation of the finding is not clear due to several different outcomes in the two studies. Nevertheless, if the findings are accepted for establishing a guideline value for FA, peak exposures have to be below $2 \mathrm{ppm}$ and average exposures below $0.5 \mathrm{ppm}$. No excess risk was observed for Hodgkin's disease, non-Hodgkin's lymphoma, multiple myelomas and leukemia in the UK cohort (Coggon et al. 2003), which also has a high exposure level. In contrast, the US NIOSH cohort showed an increase in leukemia (Pinkerton et al. 2004), although it had the lowest exposure level. The overall conclusion from the comparison of the meta-analyses (Collins and Lineker 2004; Bosetti et al. 2008; Zhang et al. 2009; Bachand et al. 2010) suggests that the association between FA exposures and the malignancies is limited to the high exposure levels if caused by FA.

The meta-analysis based on the highest exposure levels reported that FA exposures were associated with occurrence of leukemia and especially myeloid leukemia (Zhang et al. 2009). Three hypotheses were proposed as explanation. First, FA could be transported by the blood to the bone marrow where it could cause initiation in a stem or progenitor cell. Second, as a portion of the bone marrow stem and the progenitor cells circulates in the peripheral blood, they may be initiated by FA absorbed into the blood. Third, initiation of the primitive pluripotent stem cells presented within the nasal mucosa could occur followed by transport to the bone marrow. These hypotheses were addressed in comprehensive evaluations (Heck and Casanova 2004; Golden et al. 2006; Pyatt et al. 2008). The first hypothesis is not in accordance with the lack of toxic effects on the bone marrow (a target organ of known leukemogenic compounds), the negligible increase in blood FA levels in inhalation studies, and the lack of leukemogenic effect in animal studies. The second hypothesis does not comply with the negligible transport of FA to the blood and with lack of leukemia in experimental animals. Neither was a local effect, the third hypothesis, considered likely as no consistent effect was observed in the numerous animal studies; humans and animals have the same types of nasal tissue.

Overall, nasal (portal-of-entry) effects caused by high FA exposure levels could be a plausible mechanism for Hodgkin's disease, but human studies on lymphohematopoietic malignancies are inconsistent in general. For risk characterization of lymphohematopoietic malignancies, it is considered sufficient that mean exposures are below $0.5 \mathrm{ppm}$ and peak exposures below $2 \mathrm{ppm}$. The studies used to derive the values may not express cause-effect relationships. For risk characterization, it is therefore accepted that a derived indoor air guideline must be below these values.

\section{Nasal cancer}

In the recent epidemiological studies, nasopharyngeal cancer was not observed with mean exposure levels below $1 \mathrm{ppm}$ and peak levels below $4 \mathrm{ppm}$, which is consistent with studies in animals (Table 1). However, the limited consistency of the epidemiological studies and the difficulty in obtaining consistent exposure-response relationships from the studies led a recent comprehensive review to conclude that "human studies fail to raise a convincing conclusion concerning the carcinogenicity of FA and are not helpful to delineate a possible dose-response relationship" (Duhayon et al. (2008). Therefore, we depart from the nasal effects in rats for the purpose of proposing a health-based indoor air guideline value.

Three competitive approaches are used:

- The NOAEL approach is based mainly on the strongly non-linear relationship between FA exposure and development of SCC in rats (Table 1) by and large corroborated by the epidemiological studies. For additional support, see Table 4. This approach accepts that the decrease in the carcinogenic effect is so rapid that the observed NOAEL resembles a true NOAEL that is substantiated by the steep exposure-response relationship (Table 1). Also, SCC appeared at exposure levels, where the detoxification mechanism had been overwhelmed as the half-saturation of the enzyme system was observed at $2.6 \mathrm{ppm}$ FA. At lower exposure levels, no SCC appeared and free FA is low in the nasal tissue, substantiated from the lack of tissue damage below 
Table 4 Summary of approaches used in the risk assessment strategies for formaldehyde (FA)

\begin{tabular}{|c|c|c|}
\hline Effect & Supporting a NOAEL approach & Supporting a linear extrapolation \\
\hline $\begin{array}{l}\text { Repair of DNA-protein } \\
\text { crosslinks }\end{array}$ & No accumulation of DPX based on rapid in vivo repair in rats & $\begin{array}{l}\text { Accumulation of DPX based on in vitrc } \\
\text { immortalized cell lines }{ }^{\mathrm{a}}\end{array}$ \\
\hline $\begin{array}{l}\text { DPX formation in } \\
\text { lymphocyte cultures }\end{array}$ & $\begin{array}{l}\text { DPX formation was non-linear and the DPX level in non-exposed cells } \\
\text { was similar to DPX in cells at low FA levels }\end{array}$ & - \\
\hline $\begin{array}{l}\text { Genotoxic effects in nasal } \\
\text { and buccal mucosa cells }\end{array}$ & $\begin{array}{l}\text { Chromosomal aberrations and } \mathrm{MN} \text { are considered to be sensitive genetic } \\
\text { endpoints. Both are suggested to show NOAEL at indoor air levels }\end{array}$ & $\begin{array}{l}\text { A NOAEL is not accepted for FA } \\
\text { induced genotoxic effects }\end{array}$ \\
\hline $\begin{array}{l}\text { Genotoxic effects in } \\
\text { peripheral lymphocytes }\end{array}$ & In vitro cytogenetic tests suggested NOAEL & $\begin{array}{l}\text { NOAEL is not accepted for FA induced } \\
\text { genotoxic effects }\end{array}$ \\
\hline $\begin{array}{l}\text { Development of nasal } \\
\text { tumors }\end{array}$ & $\begin{array}{l}\text { In rats, the exposure-effect relationship was non-linear with an apparent } \\
\text { NOAEL }\end{array}$ & $\begin{array}{l}\text { A linear exposure-response relationship } \\
\text { at low exposures cannot be disproved } \\
\text { statistically }\end{array}$ \\
\hline $\begin{array}{l}\text { Development of nasal } \\
\text { tumors }\end{array}$ & $\begin{array}{l}\text { In rats, cell proliferation was considered crucial for development of } \\
\text { tumors }\end{array}$ & $\begin{array}{l}\text { Assuming that tumor development may } \\
\text { occur without cytotoxicity induced } \\
\text { increase in cell proliferation }\end{array}$ \\
\hline $\begin{array}{l}\text { Development of nasal } \\
\text { tumors }\end{array}$ & $\begin{array}{l}\text { In rats, a minimum FA exposure level was necessary even in the case of } \\
\text { cell proliferation }\end{array}$ & $\begin{array}{l}\text { Assuming that all FA exposure levels } \\
\text { increase the risk of development of } \\
\text { tumors }\end{array}$ \\
\hline $\begin{array}{l}\text { Nasopharyngeal cancer in } \\
\text { humans }\end{array}$ & $\begin{array}{l}\text { The FA-induced effects seem to occur at high exposure levels, especially } \\
\text { high peak levels. An apparent level exists where no increased risk was } \\
\text { observed }\end{array}$ & $\begin{array}{l}\text { Due to a limited number of cases, a low- } \\
\text { level exposure risk cannot be } \\
\text { disproved }\end{array}$ \\
\hline $\begin{array}{l}\text { Lymphohematopoietic } \\
\text { malignancies in humans }\end{array}$ & $\begin{array}{l}\text { Although limited consistency exists across studies, potential effects seem } \\
\text { to occur at high exposure levels, especially high peak levels. An } \\
\text { apparent level exists where no increased risk was observed }\end{array}$ & $\begin{array}{l}\text { Due to a limited number of cases, a low- } \\
\text { level exposure risk cannot be } \\
\text { disproved }\end{array}$ \\
\hline
\end{tabular}

For explanations see text

${ }^{a}$ Subramaniam et al. (2007)

1 ppm FA. Additionally, the tissue damage-driven cell proliferation has experimentally been demonstrated to play a key role in the development of SCC. Accepting these arguments, an indoor air guideline value can be set by dividing the appropriate NOAEL by one or more assessment factors (Nielsen and Øvreb $\varnothing$ 2008). This approach considers the NOAEL for SCC in rats (2 ppm) and the NOAEL for nasal cytotoxicity in rats (1 ppm). From the higher FA-induced DPX formation in rats compared to monkeys, it appears that no assessment factor is needed by extrapolation from rats to humans. The intra human variation has to consider that the FA-induced nasal cancer is a local effect. Also, the FA-induced DPX formation in children, often considered especially sensitive, is estimated to be lower than in adults. This suggests a limited variation within the human population. Therefore, the use of a default factor of ten for intraspecies variation will greatly overestimate the risk due to variations within humans. However, if this factor is retained, it results in a derived indoor air guideline value of $0.1 \mathrm{ppm}$ $\left(0.123 \mathrm{mg} \mathrm{m}^{-3}\right)$. This value is below all guidance values derived from the epidemiological studies, and thus considered to be protective for all types of cancer, including lymphohematopoietic malignancies.
- The low-dose linear extrapolation approach is mainly supported by worst-case assumptions (Table 4). The approach is based on the theoretical assumption of a linear relationship between FA exposure and a genetic damage (e.g. DPX formation) that induces cancer. A linear relationship between FA exposure and DPX formation in vivo has been suggested from few points below exposures, where SCC has been observed in rats (e.g. Casanova et al. 1989, 1994); a slight but significant covalent binding of FA to DNA was detected at $0.3 \mathrm{ppm}$ that increased disproportionately at $2 \mathrm{ppm}$ and higher FA concentrations (Casanova et al. 1989, 1994). The low-dose linear extrapolation approach disregards the fact that increased cell proliferation has been suggested to be a prerequisite for a FA-induced cancer in animals in addition to the requirement for a certain FA level, see the animal section. The linear risk characterization approach should be considered a type of "worst-case scenario".

- To obtain a deeper knowledge and thus a better risk characterization, a biological motivated model has been developed. It models exposures by computational fluid dynamics and the development of cancer from a twostage clonal growth model (WHO 2002; Conolly et al. 2003 , 2004). Formaldehyde was assumed to act as a 
direct mutagen with the effect considered proportional to the concentration of the pro-mutagenic DPX lesion. The DPX formation is considered linearly related to the FA concentration. At high concentrations, the model includes that cytolethality is followed by increased cell proliferation. Mutations are considered to occur during cell division processes and a tumor cell arises when an initiated cell (modeled by DPX levels) acquires a second mutation (WHO 2002; Conolly et al. 2003). Several of the parameters were estimated from the best fit of the model to the experimental data (Conolly et al. 2003). The biological motivated model was extended to humans and took into account that humans are oronasal breathers (WHO 2002; Conolly et al. 2004). For the general population, the predicted additional risk of upper respiratory tract cancer for non-smokers, associated with an 80-year continuous exposure to levels of 0.1 ppm FA was about $2.7 \times 10^{-8}$ (WHO 2002). The additional risk was estimated to be $10^{-6}$ or less in non-smokers exposed continuously for $0.2 \mathrm{ppm}$ FA (Conolly et al. 2004).

Subramaniam et al. (2008) identified key biological and statistical uncertainties of the Conolly et al. (2003) rat model and its extension to human exposures. Uncertainties comprise variability of FA-induced cell replication, sensitivity to the estimates for initiated cell formation and death rate, and extrapolation of parameters to those in the human model. Additionally, the use of DPX as a surrogate of mutagenicity was proposed to underestimate FA induced cancer. The robustness of the Conolly et al. (2004) estimate was further challenged by sensitivity analyses (Subramaniam et al. 2007; Crump et al. 2008) and further discussed (Conolly et al. 2009; Crump et al. 2009). There were two main outcomes of the analyses, which contradicted the Conolly et al. estimate. First, it is not considered possible to establish a reliable control group of non-exposed rats for a rare disease as SCC in rats. This is necessary for obtaining a reliable risk estimate. Second, it was not considered possible to obtain reliable parameters of the model, especially those for the initiated cell.

\section{Sensitive groups}

A recent model study showed that FA exposure of children would result in less DPX formation in the airways than it would in adults (Firestone et al. 2008). Interhuman variability in the nasal dosimetry of FA was investigated by means of computational fluid dynamics models in five adults and two children, aged 7 and 8. The simulations predicted the intrahuman variability to be 1.6-fold among the individuals. No significant differences were noted between the two age groups (Garcia et al. 2009). In consequence, children are not expected to be more sensitive to a carcinogenic effect of FA than adults and, thus, are not considered separately in the further evaluation.

\section{Indoor air guideline level for prevention of cancer}

Formaldehyde is a normal component of the blood. In humans, exposure to about 2 ppm airborne FA did not increase the blood level and exposure to 0.4 ppm FA did not increase urinary formate excretion due to a rapid metabolism (IARC 2006). No significant increase in blood FA levels was predicted in the exposure range from 0.1 to 10 ppm FA in a toxicokinetic model (Franks 2005). In monkeys, $6 \mathrm{ppm}$ FA, $6 \mathrm{~h} \mathrm{day}^{-1}, 5$ days week $^{-1}$ in 4 weeks did not increase the blood FA level. In rats, the half-time of FA is about $1 \mathrm{~min}$ in the plasma after intravenous administration (IARC 2006). This suggests that normal indoor air levels of FA are not expected to increase internal organ exposures, and indoor air effects of FA are expected to be limited to effects at the portal-of-entry.

Risk characterization of the carcinogenic effect of FA exposures has been based on two different approaches; the bases are summarized in Table 4. The NOAEL approach accepts the non-linear dose-response relationship apparent from the experimentally accessible part of the relationship in addition to cytotoxicity as a key mechanism. Both are experimentally supported. The linear extrapolation model is supported from more extreme ("worst-case") toxicological parameters, which suggest a low-dose linear relationship for the carcinogenic effect in the scientifically non-accessible part of the exposureresponse curve, which neither can be ruled out nor can be supported experimentally.

Based on the comparisons of the arguments in Table 4, we favor the NOAEL approach for risk assessment of FA-induced nasal effects and the use of one or more assessment factors (Nielsen and Øvrebø 2008). This approach reaches the conclusion that $0.1 \mathrm{ppm}(0.123$ $\mathrm{mg} \mathrm{m}^{-3}$ ) FA will not give rise to a cancer risk in the general population. The estimates from the biological motivated models (WHO 2002; Conolly et al. 2004) suggest a negligible risk for the general population about 0.1 to $0.2 \mathrm{ppm}$. The two approaches overall reached the same conclusion. Thus, accepting the previous guideline value of $0.08 \mathrm{ppm}\left(0.1 \mathrm{mg} \mathrm{m}^{-3}\right)$ set by the WHO (2000), this introduces an additional margin-of-exposure. In conclusion, the WHO (2000) guideline value is considered defendable for prevention of all types of cancer, including lymphohematopoietic malignancies.

Acknowledgments The work was partially carried out in the framework of the WHO Indoor Air Quality Guideline development 
(2006-2009). Partial support was also obtained from the Centre for Indoor Climate and Diseases in Dwellings supported financially by Real Dania.

Open Access This article is distributed under the terms of the Creative Commons Attribution Noncommercial License which permits any noncommercial use, distribution, and reproduction in any medium, provided the original author(s) and source are credited.

\section{Appendix}

Literature search was in PubMed with search terms "formaldehyde AND indoor air AND concentration*", "formaldehyde AND DNA-protein crosslink*", "formaldehyde AND genotox* AND blood AND lymphocyte*", "lymphatic AND tissue AND nose AND review", "micronucleus AND test AND review", "formaldehyde AND cancer AND meta-analysis", "formaldehyde AND cancer AND humans", "unit risk' AND formaldehyde", "Epstein-Barr AND nasopharyngeal cancer AND review", "Hauptmann M AND nasopharyngeal carcinoma", "Hauptmann M AND silver smithing", "silver smithing AND nasopharyngeal carcinoma", "silver smithing AND cancer", "acid AND nasopharyngeal carcinoma AND review", "nickel AND nasopharyngeal carcinoma" "unit risk AND cancer AND review" and "Zhang L AND formaldehyde". Additionally, references were obtained from IARC (2006), SCOEL (2008), Bosetti et al. (2008). Two recent studies were provided by the IARC.

\section{References}

American Conference of Governmental and Industrial Hygienists (ACGIH) (2007) TLVs and BEIs. Based on the Documentation of the Threshold Limit Values for Chemical Substances and Physical Agents and Biological Exposure Indices. ACGIH, Cincinnati

Appel K-E, Bernauer U, Herbst U, Madle S, Schulte A, RichterReichhelm H-B, Gundert-Remy U (2006) Kann für Formaldehyd eine "sichere" Konzentration abgeleitet werden? Analyse der Daten zur krebserzeugenden Wirkung. Umweltmedizin in Forschung und Praxis 11:347-361

Appelman LM, Woutersen RA, Zwart A, Falke HE, Feron VJ (1988) One-year inhalation toxicity study of formaldehyde in male rats with damaged or undamaged nasal mucosa. J Appl Toxicol 8:85-90

Arts JHE, Rennen MAJ, de Heer C (2006) Inhaled formaldehyde: evaluation of sensory irritation in relation to carcinogenicity. Regul Toxicol Pharmacol 44:144-160

Azuma K, Uchiyama I, Ikeda K (2007) The risk screening for indoor air pollution chemicals in Japan. Risk Anal 27:1623-1638

Bachand A, Mundt KA, Mundt DJ, Montgomery RR (2010) Epidemiological studies of formaldehyde exposure and risk of leukemia and nasopharyngeal cancer: a meta-analysis. Crit Rev Toxicol 40:85-100
Baan R, Grosse Y, Straif K, Secretan B, El Ghissassi F, Bouvard V, Benbrahim-Tallaa L, Guha N, Freeman C, Galichet L, Cogliano V (2009) A review of human carcinogens-Part F: chemical agents and related occupations. Lancet Oncol 10:1143-1144

Barker S, Weinfeld M, Murray D (2005) DNA-protein crosslinks: their induction, repair, and biological consequences. Mutat Res 589:111-135

Bauchinger M, Schmid E (1985) Cytogenetic effects in lymphocytes of formaldehyde workers of a paper factory. Mutat Res 158:195199

Blair A, Zheng T, Linos A, Stewart PA, Zhang YW, Cantor KP (2000) Occupation and leukaemia: a population-based casecontrol study in Iowa and Minnesota. Am J Ind Med 40:3-14

Bosetti C, McLaughlin JK, Tarone RE, Pira E, La Vecchia C (2008) Formaldehyde and cancer risk: a quantitative review of cohort studies through 2006. Ann Oncol 19:29-43

Burgaz S, Erdem O, Cakmak G, Erdem N, Karakaya A, Karakaya AE (2002) Cytogenic analysis of buccal cells from shoe-workers and pathology and anatomy laboratory workers exposed to n-hexan, toluene, methyl ethyl ketone and formaldehyde. Biomarkers 7:151-161

California Environmental Protection Agency (Cal EPA) (2005) Air toxics hot spots program risk assessment guidelines. Part II. Technical support document for describing available cancer potency factors. http://www.oehha.ca.gov/air/hot_spots/pdf/May 2005Hotspots.pdf. Assessed: 23 December 2008

Casanova M, Heck HD, Everitt JI, Harrington WW, Popp JA (1988) Formaldehyde concentrations in the blood of rhesus monkeys after inhalation exposure. Food Chem Toxicol 26:715-716

Casanova M, Deyo DF, Heck HD (1989) Covalent binding of inhaled formaldehyde to DNA in the nasal mucosa of Fisher 344 rats: analysis of formaldehyde and DNA by high-performance liquid chromatography and provisional pharmacokinetic interpretation. Fundam Appl Toxicol 12:397-417

Casanova M, Morgan KT, Steinhagen WH, Everitt JI, Popp JA, Heck HD (1991) Covalent binding of inhaled formaldehyde to DNA in the respiratory tract of rhesus monkeys: pharmacokinetics, ratto-monkey interspecies scaling, and extrapolation to man. Fundam Appl Toxicol 17:409-428

Casanova M, Morgan KT, Gross EA, Moss OR, Heck HD (1994) DNA-protein cross-links and cell replication at specific sites in the nose of F344 rats exposed subchronically to formaldehyde. Fundam Appl Toxicol 23:525-536

Chang ET, Adami H-O (2006) The enigmatic epidemiology of nasopharyngeal carcinoma. Cancer Epidemiol Biomarkers Prev 15:1765-1777

Coggon D, Harris EC, Poole J, Palmer KT (2003) Extended follow-up of a cohort of British chemical workers exposed to formaldehyde. J Natl Cancer Inst 95:1608-1615

Cole P, Axten C (2004) Formaldehyde and leukaemia: an improbable causal relationship. Regul Toxicol Pharmacol 40:107-112

Collins JJ, Lineker GA (2004) A review and meta-analysis of formaldehyde exposure and leukemia. Regul Toxicol Pharmacol 40:81-91

Collins JJ, Esmen NA, Hall TA (2001) A review and meta-analysis of formaldehyde exposure and pancreatic cancer. Am J Ind Med 39:336-345

Conolly RB, Kimbell JS, Janszen D, Schlosser PM, Kalisak D, Preston J, Miller FJ (2003) Biologically motivated computational modeling of formaldehyde carcinogenicity in the F344 rat. Toxicol Sci 75:432-447

Conolly RB, Kimbell JS, Janszen D, Schlosser PM, Kalisak D, Preston J, Miller FJ (2004) Human respiratory tract cancer risks of inhaled formaldehyde: dose-response predictions derived from biologically-motivated computational modeling of a combined rodent and human dataset. Toxicol Sci 82:279-296 
Conolly RB, Miller FJ, Kimbell JS, Janszen D (2009) Letter to the Editor. Formaldehyde risk assessment. Ann Occup Hyg 53:181189

Costa S, Coelho P, Costa C, Silva S, Mayan O, Santos LS, Gaspar J, Teixeira JP (2008) Genotoxic damage in pathology anatomy laboratory workers exposed to formaldehyde. Toxicology 252:40-48

Crump KS, Chen C, Fox JF, van Landingham C, Subramaniam R (2008) Sensitivity analysis of biologically motivated model for formaldehyde-induced respiratory cancer in humans. Ann Occup Hyg 52:481-495

Crump KS, Chen C, Fox JF, Subramaniam R, van Landingham C (2009) Reply. Ann Occup Hyg 53:184-189

Dalbey WE (1982) Formaldehyde and tumors in hamster respiratory tract. Toxicology 24:9-14

De Bruin YB, Koistinen K, Kephalopoulos S, Geiss O, Tirendi S, Kotzias D (2008) Characterisation of urban inhalation exposures to benzene, formaldehyde and acetaldehyde in the European Union. Environ Sci Pollut Res 15:417-430

Deutsche Forshungsgemeinschaft (DFG) (2009) List of MAK and BAT values 2009. Wiley-VCH Verlag, Weinheim

Dodson RE, Houseman EA, Levy JI, Spengler JD, Shine JP, Bennett DH (2007) Measured and modeled personal exposures to and risks from volatile organic compounds. Environ Sci Technol 41:8498-8505

Duhayon S, Hoet P, van Maele-Fabry G, Lison D (2008) Carcinogenic potential of formaldehyde in occupational settings: a critical assessment and possible impact on occupational exposure levels. Int Arch Occup Environ Health 81:695-710

Empfehlung des Umweltbundesamtes (2006) Krebserzeugende Wirkung von Formaldehyd-Änderung des Richtwertes für die Innenraumluft von $0,1 \mathrm{ppm}$ nicht erforderlich. BundesgesundheitsblattGesundheitsforschung-Gesundheitsschutz 49:1169

Fenech M (1997) The advantages and disadvantages of the cytokinesis-blok micronucleus method. Mutat Res 392:11-18

Feron VJ, Bruyntjes JP, Woutersen RA, Immel HR, Appelman LM (1988) Nasal tumours in rats after short-term exposure to a cytotoxic concentration of formaldehyde. Cancer Lett 39:101111

Firestone M, Sonawane B, Barone S, Salmon AG, Brown JP, Hattis D, Woodruff T (2008) Potential new approaches for children's inhalation risk assessment. J Toxicol Environ A 71:208-217

Fleig I, Petri N, Stocker WG, Thiess AM (1982) Cytogenetic analyses of blood lymphocytes of workers exposed to formaldehyde in formaldehyde manufacturing and processing. J Occup Med 24:1009-1012

Franks SJ (2005) A mathematical model for the absorption and metabolism of formaldehyde vapour by humans. Toxicol Appl Pharmacol 206:309-320

Freeman LEB, Blair A, Lubin JH, Stewart PA, Hayes RB, Hoover RN, Hauptmann M (2009) Mortality from lymphohematopoietic malignancies among workers in formaldehyde industries: the National Cancer Institute cohort. J Natl Cancer Inst 101:751-761

Garcia GJM, Schroeter JD, Segal RA, Stanek J, Foreman GL, Kimbell JS (2009) Dosimetry of nasal uptake of water-soluble and reactive gases: a first study of interhuman variability. Inhal Toxicol 21:607-618

Golden R, Pyatt D, Shields PG (2006) Formaldehyde as a potential human leukemogen: an assessment of biological plausibility. Crit Rev Toxicol 36:135-153

Hansen J, Olsen JH (1995) Formaldehyde and cancer morbidity among male employees in Denmark. Cancer Causes Control 6:354-360

Hauptmann M, Lubin JH, Stewart PA, Hayes RB, Blair A (2003) Mortality from lymphohematopoietic malignancies among workers in formaldehyde industries. J Natl Cancer Inst 95:1615-1623
Hauptmann M, Lubin JH, Stewart PA, Hayes RB, Blair A (2004) Mortality from solid cancers among workers in formaldehyde industries. Am J Epidemiol 159:1117-1130

Hauptmann M, Lubin JH, Stewart PA, Hayes RB, Blair A (2005) The authors reply. Am J Epidemiol 161:1089-1091

Hauptmann M, Stewart PA, Lubin JH, Freeman LEB, Hornung RW, Herrick RF, Hoover RN, Fraumeni JF, Blair A, Hayes RB (2009) Mortality from lympho hematopoietic malignancies and brain cancer among embalmers exposed to formaldehyde. J Natl Cancer Inst 101:1696-1708

Hayes RB, Blair A, Stewart PA, Herrick RF, Mahar H (1990) Mortality of U.S. embalmers and funeral directors. Am J Ind Med 18:641-652

Hayes RB, Klein S, Suruda A, Schulte P, Boeniger M, Stewart P, Livingston GK, Oesch F (1997) O O $^{6}$-Alkylguanine DNA alkyl transferase activity in student embalmers. Am $\mathrm{J}$ Ind Med $31: 361-365$

He J-L, Jin L-F, Jin H-Y (1998) Detection of cytogenetic effects in peripheral lymphocytes of students exposed to formaldehyde with cytokinesis-blocked micronucleus assay. Biomed Environ Sci 11:87-92

Heck H, Casanova M (2004) The implausibility of leukemia induction by formaldehyde: a critical review of the biological evidence on distant-site toxicity. Regul Toxicol Pharmacol 40:92-106

Hildesheim A, Dosemeci M, Chan C-C, Chen C-J, Cheng Y-J, Hsu M-M, Chen I-H, Mittl BF, Sun B, Levine PH, Chen J-Y, Brinton LA, Yang C-S (2001) Occupational exposure to wood, formaldehyde, and solvent and risk of nasopharyngeal carcinoma. Cancer Epidemiol Biomarkers Prev 10:1145-1153

Integrated Risk Information System (IRIS) (1991) Formaldehyde (CASRN 50-00-0). http://www.epa.gov/NCEA/iris/subst/0419.htm. Accessed: 19 January 2008

International Agency for Research on Cancer (IARC) (2006) Formaldehyde, 2-Butoxyethanol and 1-tert-Butoxypropanol2-ol. IARC monographs on the evaluation of carcinogenic risks to humans, vol 88. World Health Organization, Lyon, pp 39-325

Kamata E, Nakadate M, Uchida O, Ogawa Y, Suzuki S, Kaneko T, Saito M, Kurokawa Y (1997) Results of a 28-month chronic inhalation toxicity study of formaldehyde in male Fisher-344 rats. J Toxicol Sci 22:239-254

Kerns WD, Pavkov KL, Donofrio DJ, Gralla EJ, Swenberg JA (1983) Carcinogenicity of formaldehyde in rats and mice after longterm inhalation exposure. Cancer Res 43:4382-4392

Khoshdel A, Attia J, Carney SL (2006) Basic concepts in metaanalysis: a primer for clinicians. Int J Clin Pract 60:1287-1294

Kitaeva LV, Mikheeva EA, Shelomova LF, Shvartsman PA (1996) Genotoxic effect of formaldehyde in somatic human cells in vivo. Genetica 32:1287-1290

Kligerman AD, Phelps MP, Erexson GL (1984) Cytogenetic analysis of lymphocytes from rats following formaldehyde inhalation. Toxicol Lett 21:241-246

Kuper CF, Arts JHE, Feron VJ (2003) Toxicity to nasal-associated lymphoid tissue. Toxicol Lett 140-141:281-285

Kuper CF, van Oostrum L, Ma-Hock L, Durrer S, Woutersen RA (2010) Hyperplasis of the lymphoepithelium of NALT in rats but not in mice upon 28-day exposure to $15 \mathrm{ppm}$ formaldehyde vapor. Exp Toxicol Pathol (in press)

Lazutka JR, Lekevicius R, Dedonyte V, Maciuleviciute-Gervers L, Mierauskiene J, Rudaitiene S, Slapsyte G (1999) Chromosomal aberratins and sister-chromatid exchanges in Lithuanian populations: effects of occupational and environmental exposures. Mutat Res 445:225-239

Liteplo RG, Meek ME (2003) Inhaled formaldehyde: exposure estimation, hazard characterization, and exposure-response analysis. J Toxicol Environ Health B Crit Rev 6:85-114 
Liu Y, Li CM, Lu Z, Ding S, Yang X, Mo J (2006) Studies on formation and repair of formaldehyde-damaged DNA by detection of DNA-protein crosslinks and DNA breaks. Front Biosci 11:991-997

Loh MM, Levy JI, Spengler JD, Houseman EA, Bennett DH (2007) Ranking cancer risks of organic hazardous air pollutants in the United States. Environ Health Perspect 115:1160-1168

Marsh GM, Youk AO (2004) Reevaluation of mortality risks from leukemia in the formaldehyde cohort study of the National Cancer Institute. Regul Toxicol Pharmacol 40:113-124

Marsh GM, Youk AO (2005) Reevaluation of mortality risks from nasopharyngeal cancer in the formaldehyde cohort study of the National Cancer Institute. Regul Toxicol Pharmacol 42:275283

Marsh GM, Youk AO, Buchanich JM, Erdal S, Esmen NA (2007a) Work in the metal industry and nasopharyngeal cancer mortality among formaldehyde-exposed workers. Regul Toxicol Pharmacol 48:308-319

Marsh GM, Youk AO, Morfeld P (2007b) Mis-specified and nonrobust mortality risk models from nasopharyngeal cancer in the National Cancer Institute formaldehyde worker cohort study. Regul Toxicol Pharmacol 47:59-67

McGregor D, Bolt H, Cogliano V, Richter-Reichhelm H-B (2006) Formaldehyde and glutaraldehyde and nasal cytotoxicity: case study within the context of the 2006 IPCS human framework for analysis of a cancer mode of action for humans. Crit Rev Toxicol $36: 821-835$

Merk O, Speit G (1998) Significance of formaldehyde-induced DNAprotein crosslinks for mutagenesis. Environ Mol Mutag 32:260268

Monticello TM, Swenberg JA, Gross EA, Leininger JR, Kimbell JS, Seilkop S, Starr TB, Gibson JE, Morgan KT (1996) Correlation of regional and nonlinear formaldehyde-induced nasal cancer with proliferating populations of cells. Cancer Res 56:10121022

Naya M, Nakanishi J (2005) Risk assessment of formaldehyde for the general population in Japan. Regul Toxicol Pharmacol 43:232248

Nielsen GD, Øvrebø S (2008) Background, approaches and recent trends for setting health based occupational exposure limits: a minireview. Regul Toxicol Pharmacol 51:253-269

Ojajärvi IA, Partanen TJ, Ahlblom A, Boffetta P, Hakulinen T, Jourenkova N, Kauppinen TP, Kongevinas M, Porta M, Vainio HU, Weiderpass E, Wesselin CH (2000) Occupational exposures and pancreatic cancer: a meta-analysis. Occup Environ Med $57: 316-324$

Omae K Recommendation of Occupational Exposure Limits (20082009) (2007) The Japan society for occupational health. J Occup Health 50:426-443

Orsière T, Sari-Minodier I, Iarmarcovai G, Botta A (2006) Genotoxic risk assessment of pathology and anatomy laboratory workers exposed to formaldehyde by use of personal air sampling and analysis of DNA damage in peripheral lymphocytes. Mutat Res 605:30-41

Pinkerton LE, Hein MJ, Stayner LT (2004) Mortality among a cohort of garment workers exposed to formaldehyde: an update. Occup Environ Med 61:193-200

Pohunek P (2004) Development, structure and function of the upper airways. Paediatr Respir Rev 5:2-8

Pyatt D, Natelson E, Golden R (2008) Is inhalation exposure to formaldehyde a biologically plausible cause of lymphohematopoietic malignancies? Regul Toxicol Pharmacology 51:119-133

Quievryn G, Zhitkovich A (2000) Loss of DNA-protein crosslinks from formaldehyde-exposed cells occurs through spontaneous hydrolysis and an active repair process linked to proteosome function. Carcinogenesis 21:1573-1580
Rusch GM, Clary JJ, Rinehart WE, Bolte HF (1983) A 26-week inhalation study with formaldehyde in the monkey, rat, and hamster. Toxicol Appl Pharmacol 68:329-343

Sakai K, Nordbäck D, Mi Y, Shibata E, Kamijima M, Yamada T, Takeuchi Y (2004) A comparison of indoor air pollutants in Japan and Sweden: formaldehyde, nitrogen dioxide, and chlorinated volatile organic compounds. Environ Res 94:75-85

Salthammer T, Mentese S, Marutzky R (2010) Formaldehyde in indoor environment. Chem Rev 110:2536-2572

Sax SN, Bennett DH, Chillrud SN, Ross J, Kinney PL, Spengler JD (2006) A cancer risk assessment of inner-city teenagers living in New York City and Los Angeles. Environ Health Perspect 114:1558-1566

Schmid O, Speit G (2007) Genotoxic effects induced by formaldehyde in human blood and implications for the interpretation of biomonitoring studies. Mutagenesis 22:69-74

Scientific Committee on Occupational Exposure Limits (SCOEL) (2008) Recommendation from the Scientific Committee on Occupational Exposure Limits for formaldehyde. European Commission, SCOEL/SUM/125. http://ec.europa.eu/social/home. jsp?langId=en. Accessed 4 September 2009

Sellakumar AR, Snyder CA, Solomon JJ, Albert RE (1985) Carcinogenicity of formaldehyde and hydrogen chloride in rats. Toxicol Appl Pharmacol 81:401-406

Shaham J, Bomstein Y, Meltzer A, Kaufman Z, Palma E, Ribak J (1996) DNA-protein crosslinks, a biomarker of exposure to formaldehyde - in vitro and in vivo studies. Carcinogenesis 17:121-125

Shaham J, Bomstein Y, Melzer A, Ribak J (1997) DNA-protein crosslinks and sister chromatid exchanges as biomarkers of exposure to formaldehyde. Int J Occup Environ Health 3:95-104

Shaham J, Gurvich R, Kaufman Z (2002) Sister chromatid exchange in pathology staff occupationally exposed to formaldehyde. Mutat Res 514:115-123

Shaham J, Bomstein Y, Gurvich R, Rashkovsky M, Kaufman Z (2003) DNA-protein crosslinks and p53 protein expression in relation to occupational exposure to formaldehyde. Occup Environ Med 60:403-409

Soffritti M, Belpoggi F, Lambertini L, Lauriola M, Padovani M, Maltoni C (2002) Results of long-term experimental studies on the carcinogenicity of formaldehyde and acetaldehyde in rats. Ann N Y Acad Sci 982:87-105

Spano J-P, Busson P, Atlan D, Bourhis J, Pignon J-P, Esteban C, Armand J-P (2003) Nasopharyngeal carcinomas: an update. Eur J Cancer 39:2121-2135

Speit G, Merk O (2002) Evaluation of mutagenic effects of formaldehyde in vitro: detection of crosslinks and mutations in mouse lymphoma cells. Mutagenesis 17:183-187

Speit G, Schmid O (2006) Local genotoxic effects of formaldehyde in humans measured by the micronucleus test with exfoliated epithelial cells. Mutat Res 613:1-9

Speit G, Schmid O, Fröhler-Keller M, Lang I, Triebig G (2007) Assessment of local genotoxic effects of formaldehyde in humans measured by the micronucleus test with exfoliated buccal mucosa cells. Mutat Res 627:129-135

Speit G, Schmid O, Neuss S, Schütz P (2008) Genotoxic effects of formaldehyde in the human lung cell line A549 and in primary human nasal epithelial cells. Environ Mol Mutag 49:300-307

Speit G, Zeller J, Schmid O, Elhajouji A, Ma-Hock L, Neuss S (2009) Inhalation of formaldehyde does not induce systemic genotoxic effects in rats. Mutat Res 677:76-85

Stroup NE, Blair A, Erikson GE (1986) Brain cancer and other causes of death in anatomists. J Natl Cancer Inst 77:1217-1224

Subramaniam RP, Crump KS, van Landingham C, White P, Chen C, Schlosser PM (2007) Uncertainties in the CIIT model for formaldehyde-induced carcinogenicity in the rat: a limited sensitivity analysis-I. Risk Anal 27:1237-1253 
Subramaniam RP, Chen C, Crump KS, de Voney D, Fox JF, Portier CJ, Schlosser PM, Thompson CM, White P (2008) Uncertainties in biologically-based modelling of formaldehyde-induced respiratory cancer risk: identification of key issues. Risk Anal 28:907-921

Suruda A, Schulte P, Boeniger M, Hayes RB, Livingston GK, Steenland K, Stewart P, Herrick R, Douthit D, Fingerhut MA (1993) Cytogenetic effects of formaldehyde exposure in students of mortuary science. Cancer Epidemiol Biomarkers Prev 2:453-460

Tarone RE, McLaughlin JK (2005) Mortality from solid cancers among workers in formaldehyde industries. Am J Epidemiol 161:1089-1091

Thomson EJ, Shackleton S, Harrington JM (1984) Chromosome aberrations and sister-chromatid exchange frequencies in pathology staff occupationally exposed to formaldehyde. Mutat Res 141:89-93

Til HP, Woultersen RA, Feron VJ, Hollanders VHM, Falke HE (1989) Two-year drinking-water study of formaldehyde in rats. Food Chem Toxicol 27:77-87

Titenko-Holland N, Levine AJ, Smith MT, Quintana PJE, Boeniger M, Hayes R, Suruda A, Schulte P (1996) Quantification of epithelial cell micronuclei by fluorescence in situ hybridization (FISH) in mortuary science students exposed to formaldehyde. Mutat Res 371:237-248

Tobe M, Naito K, Kurokawa Y (1989) Chronic toxicity study on formaldehyde administered orally to rats. Toxicology 56:79-86

Vasudeva N, Anand C (1996) Cytogenetic evaluation of medical students exposed to formaldehyde vapour in the gross anatomy dissection laboratory. J Am Coll Health 44:177-179

Vaughan TL, Stewart PA, Teschke K, Lynch CF, Swanson GM, Lyon JL, Berwick M (2000) Occupational exposure to formaldehyde and wood dust and nasopharyngeal carcinoma. Occup Environ Med 57:376-384

Walrath J, Fraumeni JF (1984) Cancer and other causes of death among embalmers. Cancer Res 44:4638-4641

Wei WI, Sham JST (2005) Nasopharyngeal carcinoma. Lancet 365:2041-2054

World Health Organization (WHO) (2000) Air quality guidelines for Europe, 2nd edn. World Health Organization, Regional Office for Europe, Copenhagen, pp 87-91
World Health Organization (WHO) (2002) Formaldehyde. Concise international chemical assessment document 40. World Health Organization, Geneva

Woutersen R (2007) Indications for leukaemia and lymphoma in former animal studies. Formaldehyde International Science Conference, Barcelona, 20-21 September 2007. TNO, Toxicology and Applied Pharmacology department, the Netherlands. www.formacare.org/fileadmin/formaldehyde/PDF/Woutersen_ formaldehyde_leukemia.pdf. Accessed: 4 January 2010

Woutersen RA, van Garderen-Hoetmer A, Bruijntjes JP, Zwart A, Feron VJ (1989) Nasal tumours in rats after severe injury to the nasal mucosa and prolonged exposure to $10 \mathrm{ppm}$ formaldehyde. J Appl Toxicol 9:39-46

Wu P-C, Li Y-Y, Lee C-C, Chiang C-M, Su H-JJ (2003) Risk assessment of formaldehyde in typical office buildings in Taiwan. Indoor Air 13:359-363

Yager JW, Cohn KL, Spear RC, Fisher JM, Morse L (1986) Sisterchromatid exchanges in lymphocytes of anatomy students exposed to formaldehyde-embalming solution. Mutat Res 174:135-139

Ye X, Yan W, Xie H, Zhao M, Ying C (2005) Cytogenetic analysis of nasal mucosa cells and lymphocytes from high-level long-term formaldehyde exposed workers and low-level short-term exposed waiters. Mutat Res 588:22-27

Ying CJ, Yan WS, Zhao MY, Ye XL, Xie H, Yin SY, Zhu XS (1997) Micronuclei in nasal mucosa, oral mucosa and lymphocytes in students exposed to formaldehyde vapour in anatomy class. Biomed Environ Sci 10:451-455

Ying C-J, Ye X-L, Xie H, Yan W-S, Zhao M-Y, Xia T, Yin S-Y (1999) Lymphocyte subsets and sister-chromatid exchanges in the students exposed to formaldehyde vapour. Biomed Environ Sci 12:88-94

Zhang L, Steinmaus C, Eastmond DA, Xin XK, Smith MT (2009) Formaldehyde exposure and leukemia: a new meta-analysis and potential mechanisms. Mutat Res 681:150-168

Zhang L, Tang X, Rothman N et al (2010) Occupational exposure to formaldehyde, hematotoxicity and leukemia-specific chromosome changes in cultured myeloid progenitor cells. Cancer Epidemiol Biomarkers Prev 19:80-88 